\title{
A Short-Run View of What Computers Do: Evidence from a U.K. Tax Incentive
}

\section{September 24, 2015}

\begin{abstract}
We study the short-run, causal effect of Information and Communication Technology (ICT) adoption on the employment and wage distribution. We exploit a natural experiment generated by a tax allowance on ICT investments and find that the primary effect of ICT is to complement non-routine cognitive-intensive work. We also find that the ICT investments led to organizational changes that were associated with increased inequality within the firm and we discuss our findings in the context of theories of ICT adoption and wage inequality. We find that tasks-based models of technological change best fit the patterns that we observe.
\end{abstract}

JEL: J24, J31, J82, O33

Keywords: ICT, job polarization, wage inequality, routine-biased technical change, organizational change, tax incentive

\section{Paul Gagg| $\left.\right|^{1,2}$}

University of North Carolina at Charlotte

Belk College of Business

Department of Economics

9201 University City Blvd

Charlotte, NC 28223-0001

Email: pgaggl@uncc.edu

\section{Greg C. Wright ${ }^{1,2}$}

\author{
University of California, Merced \\ Department of Economics \\ 5200 North Lake Blvd. \\ Merced, CA 95343 \\ Email: gwright4@ucmerced.edu
}

\footnotetext{
${ }^{1}$ This work contains statistical data from the Office for National Statistics and Her Majesty's Revenue and Customs, which are Crown copyright and reproduced with the permission of the controller of HMSO and Queen's Printer for Scotland. The use of the ONS' statistical data in this work does not imply endorsement of the ONS in relation to the interpretation or analysis of the statistical data. This work uses research datasets which may not exactly reproduce National Statistics aggregates.

${ }^{2}$ For extremly helpful feedback we are grateful to David Autor, Steve Billings, Tom Blake, Craig Depken, Rowena Gray, Nir Jaimovich, Jason Lindo, Giovanni Mastrobuoni, Ankur Patel, Andrea Salvatori, Kurt Schnier, Lisa Schulkind, Caleb Stroup, Alex Whalley and seminar participants at Duke University, the 2014 and 2015 NBER Summer Institutes, the 2015 SOLE Meetings, and the 2015 All-California Labor Economics Conference.
} 


\section{Introduction}

Policymakers and researchers have recently been interested in the relationship between firms' adoption of new information and communication technologies (ICT) and the changing demand for different types of labor. A prominent example is the work by Autor, Levy and Murnane (2003), who address the question of "what computers do" by presenting correlations suggesting that ICT complements work that involves the execution of complex, non-routine workplace tasks, while to an equal or greater extent substituting for work that is highly routine. Substantial long-run evidence consistent with the Autor et al. (2003) thesis has since been presented, ${ }^{2}$ yet an important question remains: what is the direct impact of ICT investment on the demand for different types of labor within the firm? An answer to this question will not only highlight the mechanisms relating ICT to workforce changes, but will also provide evidence for policymakers, who may have short time horizons.

We address this question by exploiting a unique natural experiment generated by an unanticipated, narrowly targeted U.K. tax incentive. We then apply our research design to two complementary questions: first, to what extent are firms' labor demand responses amplified by coincident organizational changes? And second, how do the observed effects align with current theoretical models of the labor market impact of ICT?

A key challenge in testing the Autor et al. (2003) hypothesis is that over long time horizons the relative supply of different labor types varies in response to improvements in ICT. Furthermore, the opposite is also true-innovations in ICT are driven in part by changes in the skill content of the economy, an argument that has most prominently been advanced by Acemoglu (1998, 2002, 2007). More recently, this two-way interaction was the central theme of work by Goldin and Katz (2008), who document the long-run "race" between education and technology. ${ }^{3}$ As a result, in order to isolate the direct relationship between ICT

\footnotetext{
${ }^{2}$ For instance, Autor et al. (2003) present correlations between the use of personal computers (PCs) and the prevalence of nonroutine work over the period 1960 to 1998, while Akcomak, Kok and Rojas-Romagosa (2013) do so over the period 1997 to 2006. Michaels, Natraj and van Reenen (2014) take an international perspective and report conditional correlations between ICT and labor market outcomes for 11 countries over 25 years. Doms and Lewis (2006), Beaudry, Doms and Lewis (2010), as well as Autor and Dorn (2013) pursue a more causal interpretation by documenting a positive, long-run relationship between the (likely exogenous) historical concentration of routine tasks across local labor markets and subsequent workplace computer adoption. Autor and Dorn (2013) find that these historically routine intensive regions also show rising wages and employment at the tail ends of the skill distribution relative to middle skilled jobs ("job polarization"). Autor, Dorn and Hanson (2013a,b) also pursue this "tasks-based" approach to the labor market and adopt a similar indirect supply-side identification strategy. Acemoglu and Autor (2011) as well as Draca, Sadun and van Reenen (2006) provide recent reviews of this literature.

${ }^{3}$ Another potentially important long-run general equilibrium effect is suggested by Autor and Dorn (2013). They argue that the
} 
adoption and the demand for different types of labor, it is important to hold both the supply of skill and the economy-wide level of technology fixed.

We address these challenges by exploiting a generous, one-time, narrowly-targeted 100 percent tax credit for investments in ICT that was made available exclusively to small U.K. firms between 2000 and 2004. ${ }^{4}$ Since the tax incentive was largely unanticipated and, in addition, was the only tax policy targeted exclusively toward small firms at the time, it generated a sharp discontinuity in the incentive to invest in ICT at the eligibility threshold. ${ }^{5}$ Thus, any observed discontinuity in firm investment behavior at this threshold can potentially be interpreted as a causal outcome of the policy. With this in mind, we follow a standard regression discontinuity (RD) design throughout, first exploiting data from the universe of U.K. corporate tax returns to show that the introduction of this targeted tax credit differentially altered tax claims for ICT investment at the eligibility threshold. Using separate firm-level data on investments in computer hardware and software we then confirm that the additional tax claims made by small firms indeed reflected actual additional investment in ICT.

Shifting our focus to workers, we find that these additional ICT investments raised average weekly earnings, hours worked, and labor productivity within the treated group of firms. In order to explore the distributional consequences of the ICT investments we adopt the job-type classification from Acemoglu and Autor (2011), finding that the rise in earnings and employment was concentrated among workers engaged in non-routine, cognitive-intensive production tasks. ${ }^{6}$ On the other hand, we find that routine, cognitive

observed increase in the demand for low-skill, non-routine-intensive service work (e.g., health care, massage therapy, food service, etc.) throughout the 1990s and 2000s could be a consequence of ICT adoption. Specifically, they argue that the increased demand for these services may come from workers who are complementary to ICT and have therefore seen their incomes, and marginal propensity to consume services, rise.

${ }^{4}$ Our analysis complements a handful of existing studies on the short-run consequences of ICT adoption. These are based on less comprehensive datasets and have a slightly different focus. For instance, Bartel, Ichniowski and Shaw (2007) use survey responses from 212 US valve-making plants in 2002 to study potential plant-level mechanisms through which computers may enhance productivity. Among other results, they find that the "adoption of new IT-enhanced capital equipment coincides with increases in the skill requirements of machine operators, notably technical and problem-solving skills, and with the adoption of new human resource practices to support these skills." In a related paper, Brynjolfsson and Hitt (2003) study 527 large US firms over 1987-1994 and provide evidence for overall short-run firm-level productivity gains in response to computer investments, though they do not study the effect of computers on labor demand. Doms, Dunne and Troske (1997) focus on the manufacturing sector and present industry-level correlations that suggest that computers increase demand for non-production labor.

${ }^{5}$ All other corporate tax incentives applicable to small firms (with no more than 50 employees) at the time were also available to medium sized firms (with no more than 250 employees). Interestingly, Abramovsky and Griffith (2006) use the same tax incentive as we do to construct an instrumental variable in their study of services offshoring.

${ }^{6}$ Following Acemoglu and Autor (2011), we classify (1) managerial, professional and technical occupations as "non-routine cognitive"; (2) sales, clerical and administrative support occupations as "routine cognitive"; (3) production, craft, repair, and operative occupations as "routine manual"; and (4) service occupations as "non-routine manual". 
workers experienced a decline in earnings and employment while there was little evident impact on manual workers. Overall, this asymmetric pattern is consistent with an outward shift in the demand for non-routine, cognitive-intensive production tasks and an inward shift in the demand for routine, cognitive work in response to the investment in ICT. Finally, we find that the dispersion in wages among non-routine, cognitive workers increased in response to the ICT investments, while there is some evidence that wage dispersion fell among routine, cognitive workers. We later highlight this finding in our discussion of potential theoretical explanations of the results.

It is not immediately obvious why we should expect a pronounced short-run labor demand response to ICT investments. One possible explanation is that organizational changes are implemented as part of the ICT-adoption process, and these organizational changes amplify the impact of ICT. For instance, new ICT may allow firms to introduce new business processes, restructure workforce hierarchies, or monitor workers more or less intensively, which may consequently affect the productivity of different categories of workers. While the existing literature has explored the potential complementarity of ICT and organizational change, the firm's organizational status is typically either assumed to be exogenous ${ }^{7}$ or else it is endogenized but its relationship to ICT investments is not cleanly identified. ${ }^{8}$ We bring our research design to bear on these issues by applying our RD strategy to firm-level data on the implementation of organizational changes. Interestingly, we find evidence that the ICT investments were indeed accompanied by an increase in the adoption of advanced management techniques as well as additional changes in organizational structure.

Taken together with the wage and employment results, we conclude with a discussion of the extent to which the findings align with the recent tasks-based model of technological change presented in Acemoglu and Autor (2011) as well as the model of knowledge hierarchies developed in Garicano and Rossi-Hansberg (2006). There has been some debate over the relative importance of each mechanism in driving recent trends in inequality; for instance, Garicano and Rossi-Hansberg (2014) argue that in contrast to the labor literature, which focuses narrowly on the relative price of skill, their knowledge-based hierarchies model can more readily explain the recent pattern of U.S. wage polarization. With this in mind, we first argue that both models present mechanisms that are consistent with our results. In an attempt to distinguish between

\footnotetext{
${ }^{7}$ For instance, Bartel, Ichniowski and Shaw (2005), Black and Lynch (2001), and Bresnahan, Brynjolfsson and Hitt (1999).

${ }^{8}$ For example, see Acemoglu, Aghion, Lelarge, Van Reenen and Zilibotti (2006), Caroli and Van Reenen (2001), or Colombo and Delmastro (2004).
} 
the models we present additional findings indicating little impact of ICT on managerial wages, which are a subset of the non-routine, cognitive jobs we examined previously. Since the Garicano and Rossi-Hansberg (2006) model predicts increased wage dispersion among this group of workers, we suggest that this finding points toward a more prominent role for the tasks-based model relative to the knowledge hierarchy model in the short run.

Since exogenous variation in ICT investment is difficult to find, causal evidence on the direct consequences of investing in these technologies is rare. ${ }^{9}$ Two exceptions, and the analyses most closely related to ours, are provided by Akerman, Gaarder and Mogstad (2013) and De Stefano, Kneller and Timmis (2014). The former exploits the sequential rollout of broadband internet across Norway and finds a significant impact on firm performance as well as the wage distribution within firms. In contrast, the latter exploits a geographic discontinuity in the availability of broadband internet in the U.K. but finds little effect on firm performance. Our paper complements this work in that we also exploit a natural experiment in order to generate firm- and worker-level estimates. However, instead of focusing narrowly on the impact of internet access, we estimate the firm level effects of adopting computer hardware and software. This also distinguishes our work from a recent literature that proxies ICT adoption with either the number of workers that uses a PC or the number of PCs in the workplace (e.g., see Beaudry et al., 2010, Autor and Dorn, 2013, and much of the literature surveyed in Acemoglu and Autor, 2011).

Finally, we note that temporary tax incentives, like the one explored here, are a popular vehicle to promote investment. However, there is little convincing evidence on the efficacy of such policies. Our paper therefore contributes to a long debate that goes back at least to Hall and Jorgenson (1967), and is most closely related to two recent contributions that exploit similar tax incentive programs, Cohen and Cummins (2006) and House and Shapiro (2008). ${ }^{10}$

The remainder of this article is organized as follows: we begin with a detailed description of the tax policy and our data sources in Section 2. We introduce our research design and discuss its validity in Section 3. Section 4 covers our results. Section 4.1 presents estimates of the tax incentive's impact on firm

\footnotetext{
${ }^{9}$ While many of the existing contributions only present conditional correlations, attempts to identify the causal effects of ICT on workers go back at least to Krueger (1993) and DiNardo and Pischke (1997).

${ }^{10}$ For other representative contributions to this debate see Auerbach and Hassett (1991, 1992), Cummins, Hassett and Hubbard (1994, 1996), Goolsbee (1998), or Chirinko, Fazzari and Meyer (1999).
} 
investment decisions, Section 4.2 our estimates of the impact of ICT on labor market outcomes, and Section 4.3 our analysis of the relationship between ICT investment and organizational change. Section 5 discusses the results in the context of current models of ICT and wage inequality. We offer some concluding remarks in Section 6.

\section{Policy Experiment \& Data Sources}

We exploit a unique quasi-experiment due to a 100 percent first year tax allowance (FYA) on ICT investments made available to small firms in the U.K. This policy represented a particularly large investment incentive, as it allowed businesses to write off the full cost of ICT investments against their taxable profits. ${ }^{11}$ The following types of investments were eligible for the tax allowance: ${ }^{12}$

- Computer equipment comprising computers (ranging from small palmtop organizers to large systems), computer peripherals such as keyboards, printers etc; cabling and other equipment to link computers to each other, or to data networks such as the internet; and dedicated electrical systems for computers.

- High-tech communications technologies comprising WAP (wireless application protocol) phones, 3rd generation $(3 \mathrm{G})$ mobile phones and equipment with similar applications and functionality; and set-top boxes that are connected to televisions and are capable of receiving and transmitting information from and to data networks such as the internet.

- Software for use with computers or high-tech communications technologies. This covers all computer software, including new software for use on computers bought before April 1, 2000 and the costs of creating web sites.

To identify the impact of the policy, we exploit both the timing of its introduction as well as its targeted nature. The tax incentive was introduced on April 1, 2000, was initially scheduled to expire on March

\footnotetext{
${ }^{11}$ As a comparison, over the period 1998 to 2008 there was one other plant and machinery allowance available to small and medium sized firms (up to 250 employees). The rate varied over this period but was set at either 40 or 50 percent. As a further reference, in a recent paper Bøler, Moxnes and Ulltveit-Moe (2012) find a substantial response by Norwegian firms to a 20 percent tax credit on $R \& D$ investments. Overall we believe that the tax credit we examine here represented a significant incentive.

${ }^{12}$ See http://www.hmrc.gov.U.K./manuals/camanual/CA23130.htm for official documentation.
} 
31, 2003, but was then extended until March 31, 2004. The tax incentive was further restricted to "small businesses" which Her Majesty's Revenue and Customs (HMRC) defined as those satisfying at least two of the following criteria: annual turnover of no more than $£ 2.8$ million, total assets of no more than $£ 1.4$ million, and no more than 50 employees. ${ }^{13}$ We note that employment is overwhelmingly the key criterioni.e., there are very few firms with fewer than 51 employees but more than $£ 2.8$ million in turnover or $£ 1.4$ million in assets. For the purposes of our research design, it is also important to note that during this period there were no other tax allowances targeting small firms exclusively. ${ }^{14}$

We provide direct evidence on the magnitude of investments made by firms in response to the incentive by exploiting newly available, confidential tax return data from HMRC as well as data on investments in hardware and software collected by the U.K. Office of National Statistics in the Quarterly Capital Expenditure Survey (QCES). ${ }^{15}$ With respect to the first data source, we exploit the universe of plant and machinery tax allowances claimed by U.K. firms in their corporate tax returns, both during (2000 - 2004) and after the period in which the policy of interest was in place (2005 - 2007). ${ }^{16}$ While these tax returns do not tell us whether the firm claimed the specific first year allowance we are interested in (the ICT allowance), they do report the sum of all first year plant and machinery allowances claimed by each U.K. firm in a year. We therefore exploit the discontinuity in firm eligibility for the tax incentive to gauge the magnitude of ICT tax allowance claims made in response to it, as we describe further below. Since eligibility is based on firm employment, we merge the tax return data with firm information from Bureau van Dijk's FAME database, which reports (among many other things) the number of employees in each firm. The FAME data encompass all U.K. firms registered with Companies House, which is nearly all U.K. firms. Panel A of Table 1 presents descriptive statistics for the merged sample.

Since the data on tax allowance claims alone cannot provide conclusive evidence of differential investment across the eligibility threshold, we further explore the direct effect of the incentive on hardware and

\footnotetext{
${ }^{13}$ For the remainder of this article we use the term "small firm" as a synonym for the official HMRC definition.

${ }^{14}$ There were five other plant and machinery tax allowances available at different points during this period, however each targeted small and medium sized firms (those with fewer than or equal to 250 employees) rather than small firms only. These allowances targeted investments in energy saving capital (from 2001), cars with low carbon dioxide emissions (from 2002), capital for gas refueling stations (from 2002), capital for ring fence trade (from 2002), and environmentally friendly capital (from 2003).

${ }^{15}$ Note that unfortunately it is not possible to link any of the datasets used in the paper, so we rely on independent data sources.

${ }^{16}$ Specifically, we use data from Box 118 on HMRC company tax return form CT600: "Expenditure on machinery and plant on which first year allowance is claimed." This information is not currently available to researchers for the pre-2000 period.
} 
Table 1: Data Sources \& Summary Statistics

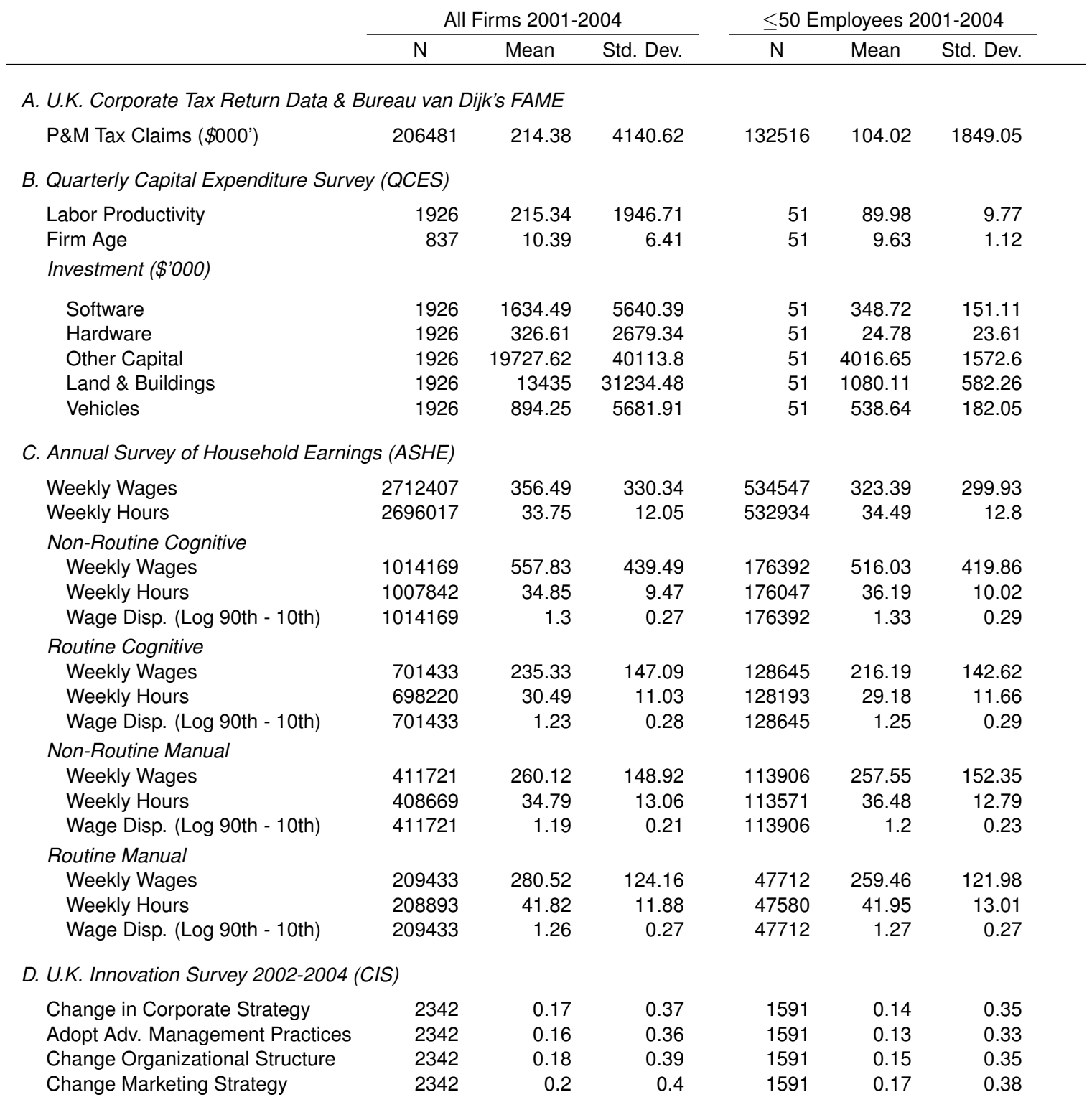

Notes: The data sources are described in the text. Panel A reports raw sample averages. Panel B reports summary statistics of a dataset that was averaged to weighted firm-size-bin means. Panel $\mathrm{C}$ reports pooled weighted averages of the indicated survey years. Panel D averages yes/no (coded 1/0) questions concerning the years 2002-2004.

software investment via the QCES, which collects quarterly data on these expenditures from a stratified sample of 26,000 to 32,000 firms, and has done so since $2001 .^{17}$ In other words, it may be the case that

\footnotetext{
${ }^{17}$ Note that the tax incentive was available from 2000 to 2004, so that the QCES data will underestimate the total effect over the period to the extent that there was significant investment made in 2000 in response to the incentive.
} 
the incentive had no impact on ICT investments, but simply allowed firms below the threshold to claim investments they would have made anyway. However, a positive finding in both datasets would provide fairly conclusive evidence that firms increased their ICT investments as a direct response to the tax incentive. Panel B of Table 1 presents descriptive statistics.

To implement our research design with respect to workers we exploit another unique dataset, the U.K. Annual Survey of Household Earnings (ASHE), an annual representative one percent sample of workers drawn from National Insurance records for working individuals. The dataset provides detailed information on the earnings and hours worked of U.K. workers along with basic employment variables such as the detailed industry and occupation of the worker. ${ }^{18}$ Importantly-and unusually-the survey also includes the number of employees associated with each worker's firm, information that we exploit in order to link each worker's employer to the eligibility criteria of the tax incentive. We include only those workers who work for private companies, since these workers are effectively "treated" by the tax incentive. It is also worth noting that because the ASHE earnings data is provided by employers, rather than employees, the reported wage and employment values are thought to be more comprehensive and accurate relative to other surveys. The data are available for the period 1997 - 2007 and summary statistics for our worker sample covering the period $2001-2004$ are provided in panel C of Table 1.

Finally, we exploit data on organizational change from the U.K. Innovation Survey, the main source of business innovation information for the U.K. The survey asks a stratified random sample of approximately 16,000 firms a series of questions with respect to their innovation activities over a prior three-year period, and in our case we exploit responses for a subset of our treatment period, 2002-2004, as well as the next available post-treatment period survey responses, which covered 2006-2008. ${ }^{19}$ Summary statistics for the first wave are provided in panel D of Table 1.

\section{Research Design}

Our primary objective is to explore the within-firm impact of policy-induced ICT investments on workers, and we undertake this analysis in Section 4.2. As a first step, we estimate a "first stage" effect in order

\footnotetext{
${ }^{18}$ Earnings values are deflated using the U.K. CPI.

${ }^{19}$ There was an intermediate survey that covered 2004-2006, which clearly overlaps with the final year of our treatment period and so is not useful as a counterfactual.
} 
to quantify the investment response by firms to the tax incentive. In a "second stage" we then estimate the impact of the tax incentive on worker outcomes which, when combined with the first stage estimates, allows for the calculation of an "implied IV" estimate of the impact of the ICT investments on labor demand within the firm. Finally, we use the same strategy to investigate the complementary role of organizational change as a co-determinant of the observed effects.

In each case we employ a standard regression discontinuity $(\mathrm{RD})$ research design that exploits firms' differential incentive to invest in ICT in the neighborhood of the 50 employee threshold (Lee and Lemieux, 2009; Imbens and Lemieux, 2008). In the context of the potential-outcomes framework, we denote $Y_{i t}$ as the outcome variable of interest-e.g., investment in ICT equipment; $Y_{i t}(1)$ as the observed value when firm $i$ is "treated" with eligibility for the ICT tax allowance in period $t$; and $Y_{i t}(0)$ as the observed value if the firm is not treated (i.e., has more than 50 employees). Further denote $E m p_{i t}$ as the number of employees in firm $i$ at time $t$. Under the assumption that the treatment is randomly assigned within a small neighborhood around the eligibility threshold, the causal impact of the treatment on the outcome variable for firms within this neighborhood is then given by

$$
\begin{aligned}
\tau_{R D} & =E\left[Y_{i t}(0)-Y_{i t}(1) \mid E m p_{i t}=50\right] \\
& =\lim _{\epsilon \downarrow 0} E\left[Y_{i t} \mid E m p_{i t}=50+\epsilon\right]-\lim _{\epsilon \uparrow 0} E\left[Y_{i t} \mid E m p_{i t}=50+\epsilon\right] \\
& =\lim _{\epsilon \downarrow 0} \mu_{+}(\epsilon)-\lim _{\epsilon \uparrow 0} \mu_{-}(\epsilon)
\end{aligned}
$$

We then obtain estimates of $\tau_{R D}$ by approximating the regression function to the right, $\mu_{+}(\epsilon)$, and to the left, $\mu_{-}(\epsilon)$, of the cutoff with kernel-based local polynomials. ${ }^{20}$ Throughout the paper we follow Calonico, Cattaneo and Titiunik (2015) as well as Calonico, Cattaneo and Titiunik (2014) to construct graphical illustrations and statistical estimates of $\tau_{R D}$. For each set of results we report estimates derived from local linear approximations and our inference is based on the bias-correction procedures described by Calonico et al. $(2014) .^{21}$

\footnotetext{
${ }^{20}$ Note that, even though treatment in our case is to the left of the cutoff, we stick with the standard notation here, which subtracts the regression function on the right from the regression function on the left. Thus, in our case, a positive treatment effect will result in a negative value of $\tau_{R D}$. Also note that, strictly speaking, the limiting arguments in the above RD design are not valid with a discrete running variable like $E m p_{i t}$, but in practice any observed measurement is discrete. Lee and Card (2008) as well as Lee and Lemieux (2009) discuss the degree to which a discrete running variable may introduce bias.

${ }^{21}$ We test the sensitivity of our results to various higher order polynomials as well as standard regression based estimates with var-
} 


\subsection{Validity of the Research Design}

Before turning to the formal analysis outlined above, we first address the validity of our research design and discuss a number of strategies we use to test our identifying assumptions. Since HMRC's definition of a small business was not introduced for this particular policy and since there were no other contemporaneous policies specific to this group of firms, we argue that eligibility for businesses close to the size threshold was effectively randomly assigned. However, to the extent that firms were able to anticipate the tax savings we might expect that firms with initially more than 50 employees may have reduced their employment in order to qualify for the incentive. On the one hand, the tax incentive was quite generous, so that the potential tax savings for firms that use ICT intensively may have been substantial. On the other hand, firing workers is costly, and U.K. labor laws are relatively strict. Perhaps a more realistic scenario is that firms who otherwise would have hired additional workers, bringing them over the 50 worker threshold, delayed hiring. These firms may not be otherwise identical to firms with just over 50 employees and the regression discontinuity design would therefore be inappropriate.

Firms who manipulate their size along the lines hypothesized above would likely be concentrated just below the eligibility cutoff in the treatment period and so, as a first pass, we examine the density of firms around the cutoff. Panels A and B in Figure 1 plot the firm size distribution for U.K. firms, drawn from FAME, for the period 1997-1999 (pre-treatment) and 2000-2004 (treatment), and alternatively for the years 1999 (just before the FYA became available) and 2000 (the first year of the FYA). These distributions suggests that there was no bunching of firms at the 50 employee threshold. Moreover, there is also no visible change in the density before and after the introduction of the ICT tax allowance.

We employ two additional strategies to further assess the possibility of size manipulation. First, in our analysis of HMRC tax claims we consider the case in which we focus exclusively on the year 2004. This final year of the policy offers an improved opportunity to test for employment size manipulation since the tax incentive was initially set to expire in 2003, but was extended for one year just after the 2003 expiration date. $^{22}$ This reduced the likelihood of manipulation in anticipation of the 2004 tax incentive and provides a

ious bandwidths and bin sizes. In an earlier version of the paper we have also explored a more traditional difference-in-differences and event study approach (Gaggl and Wright, 2014). Our results are robust to these alternative analyses and to economize on space we omit these, though they are available on request.

${ }^{22}$ Former Chancellor Gordon Brown announced the extension on April 9th, 2003. The existing incentives had just expired at the end of March, 2003. 
(A) $1999 / 2000$

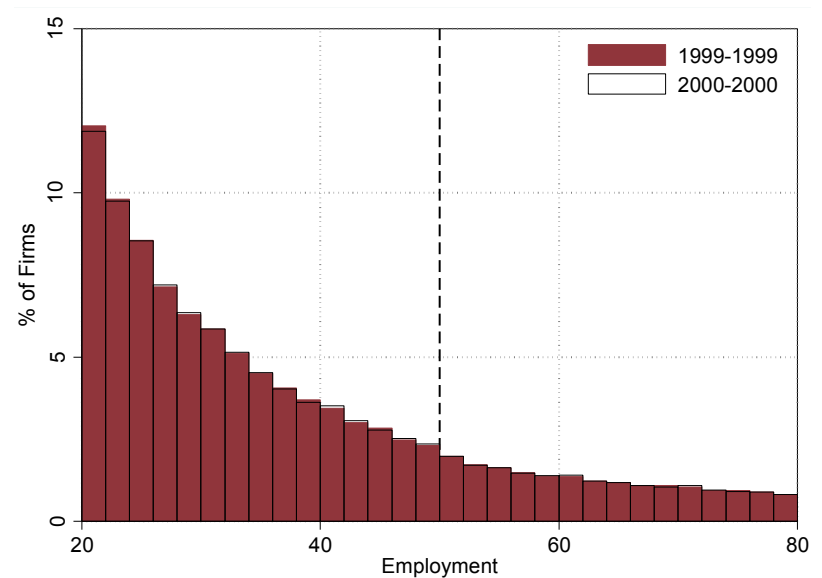

(B) Pre-Treatment/Treatment

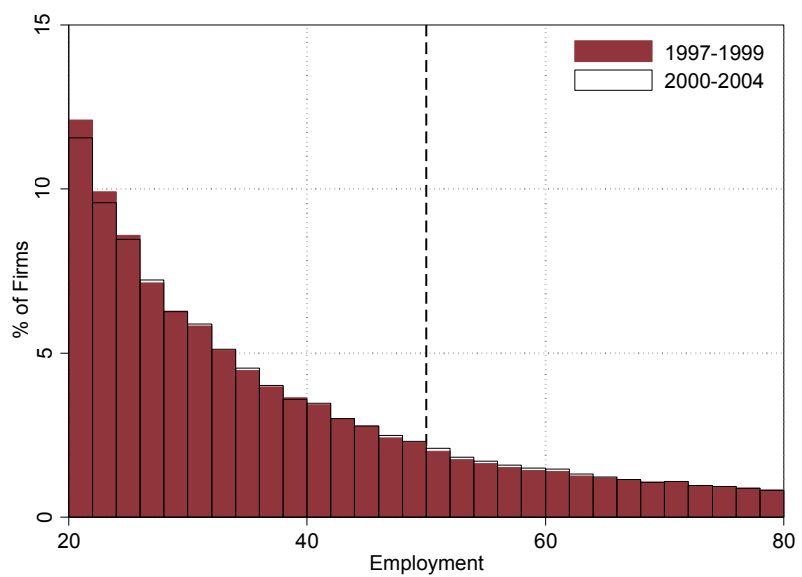

Notes: The figures plot the firm size density before and during the treatment period. Panel A illustrates the densities for 1999 and 2000. Panel B pools the period 1997-1999 and 2000-2004. The data are drawn from Bureau Van Dijk's FAME database.

useful opportunity to explore the robustness of the results. We find that the results are virtually identical to our main specifications below and therefore we do not report them separately.

Second, for several key specifications we estimate $\tau_{R D}$ using a sample in which we drop observations just below the size threshold—specifically, we drop firms with 48-50 employees. We find that the omission of these firms does not substantively change the results, suggesting that the research design does not simply identify firm selection into eligibility for the tax incentive. Due to space considerations we also do not report these results separately.

Importantly, our research design also relies on the absence of discontinuities at the eligibility threshold for firm outcomes that are exogenous to the tax policy, and in particular outcomes that are pre-determined. In the case examined here it is difficult to identify outcomes that satisfy this criterion for at least two reasons. First, almost all observed firm characteristics are potentially endogenous to the tax incentive. Second, firm entry and exit induced by the tax incentive may affect the estimated cell means, even if the chosen outcome is pre-determined at the level of the firm. For instance, firm age is certainly pre-determined, however its cell mean may be endogenous to the incentive to the extent that the incentive fostered churning in the market. On the other hand, the firm response to the incentive, while of an important magnitude, was not drastic, and particularly over this short time frame is unlikely to have altered the composition of firms to a large extent. 
Figure 2: Industry Composition

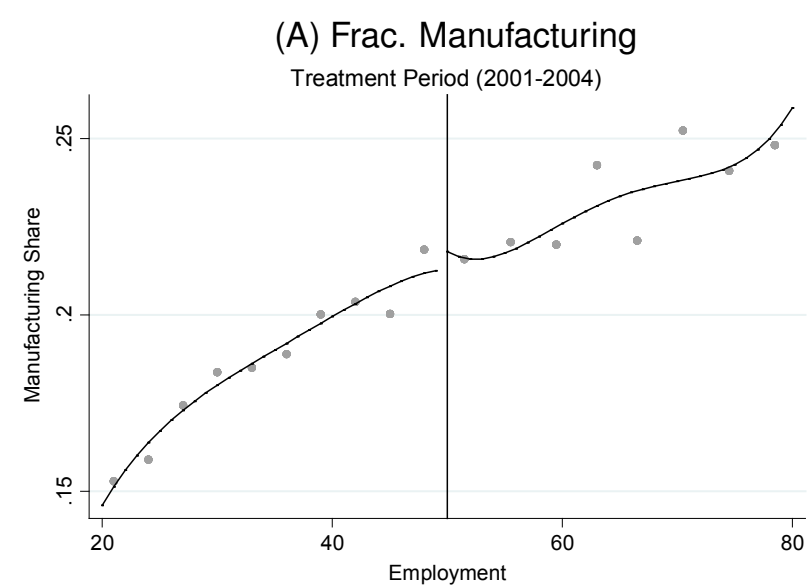

(C) Frac. Finance, Insurance \& Real Estate

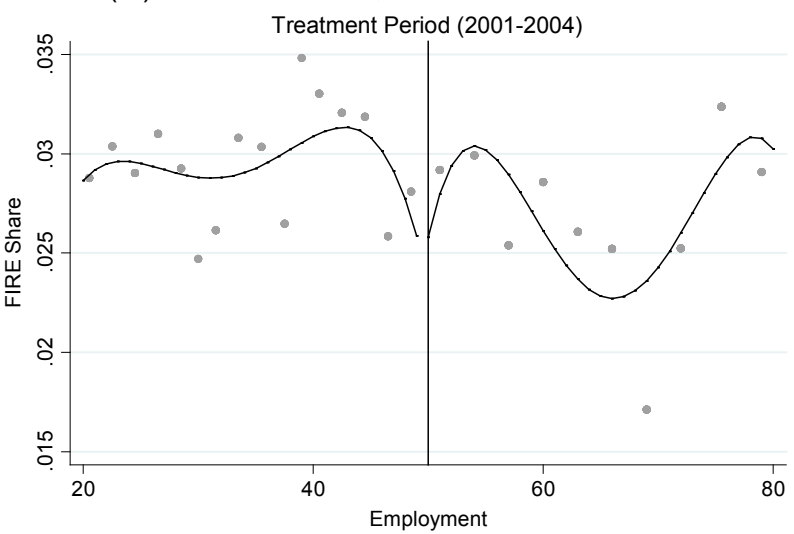

(B) Frac. Service

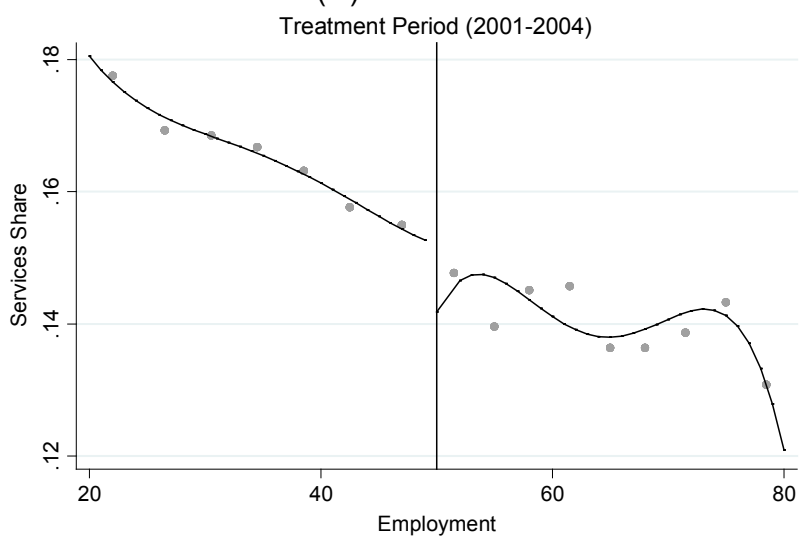

(D) Frac. Agriculture \& Mining

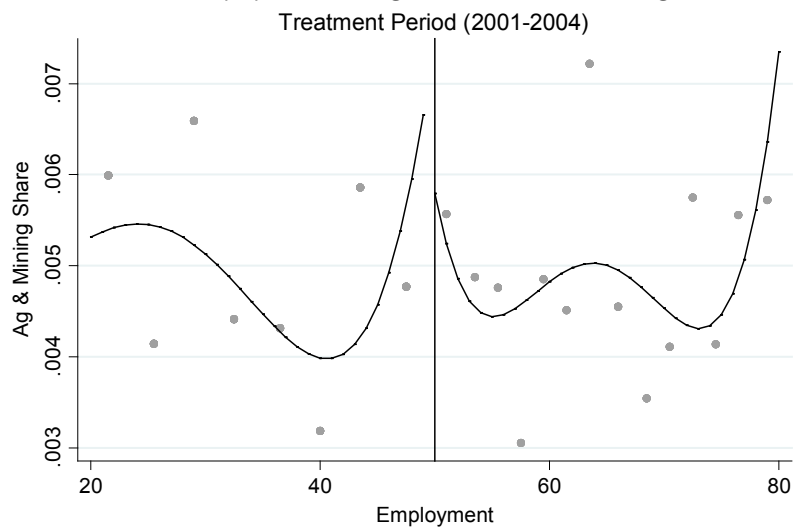

Notes: The figures illustrate the average fraction of manufacturing (panel A), service (panel B), finance, insurance, and real estate (panel C), and agriculture and mining firms (panel D) by firm employment. For these figures we choose the optimal bandwidth and bin size to the left and the right of the 50 employee cutoff based on the methods described in Calonico et al. (2015). The lines are fitted fourth order polynomials. The graphs are based on the UK Quarterly Capital Expenditure Survey (QCES).

With these caveats in mind, Figure 2 presents regression discontinuity plots of the share of firms in a particular industry by firm size. Figure 3 then plots average firm age and average investment in non-ICT capital by firm size. As expected, there is no evidence of a discontinuity in each case. ${ }^{23}$ This finding-especially Figure 3, since it focuses on non-ICT capital investments—-strongly suggests that any discontinuity in ICT investment at the 50 employee threshold is not a general feature of firms around that threshold but, rather, is likely a consequence of the targeted investment incentive.

Finally, we not only exploit the targeted nature of the tax incentive but also it's timing. The incentive was

\footnotetext{
${ }^{23}$ This observation is supported by point estimates for this exercise not separately reported here for space considerations.
} 
(C) Land \& Buildings

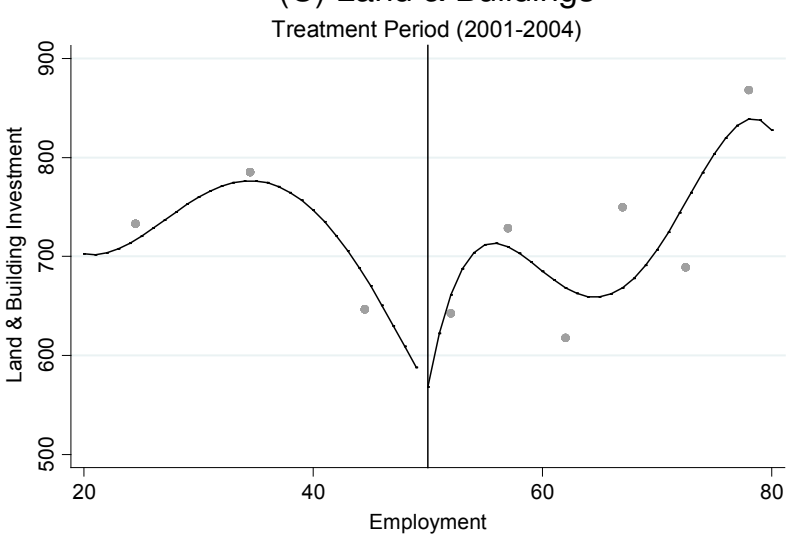

(C) Other Non-ICT Capital

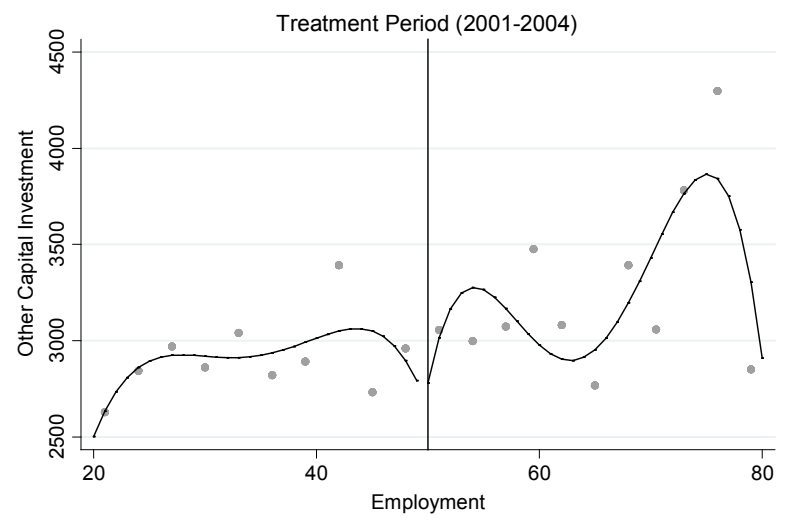

(D) Vehicle Investment

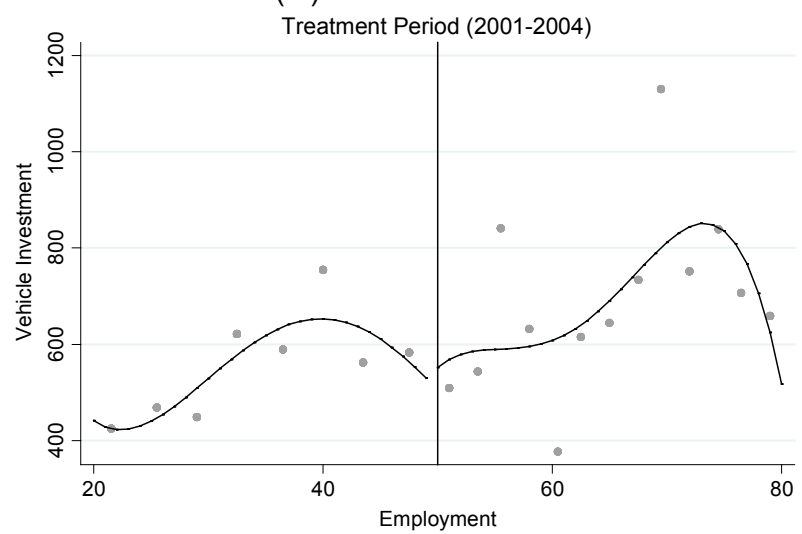

(D) Firm Age

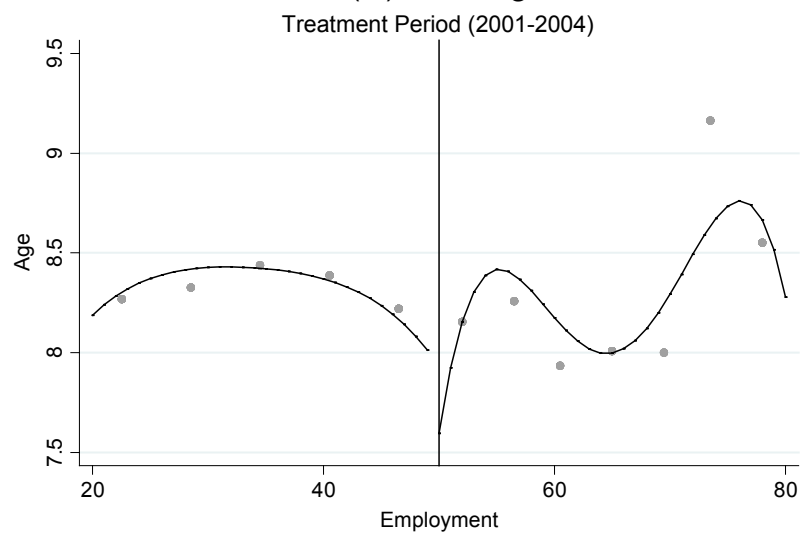

Notes: The figures illustrate investment in land and buildings (panel A), vehicles (panel B), and other non-ICT capital (panel C) by firm employment. Panel (D) illustrates firm age along the employment distribution. For these figures we choose the optimal bandwidth and bin size to the left and the right of the 50 employee cutoff based on the methods described in Calonico et al. (2015). The lines are fitted fourth order polynomials. The graphs are based on the UK Quarterly Capital Expenditure Survey (QCES).

introduced in 2000 and expired in 2004. If the effects that we identify are truly due to the tax incentive, then we would expect to find no visible discontinuity in outcomes in the pre- and post-periods, and we present evidence on this throughout.

\section{Results}

\subsection{Firm Response to the Tax Incentive}

We begin with graphical evidence from HMRC corporate tax returns over the period of interest. Figure 4 plots the average value of first year plant and machinery allowances claimed in a year by firm size, for 
Figure 4: Avg. Plant \& Machinery Tax Deductions Claimed

(A) Treatment (2000-2004)

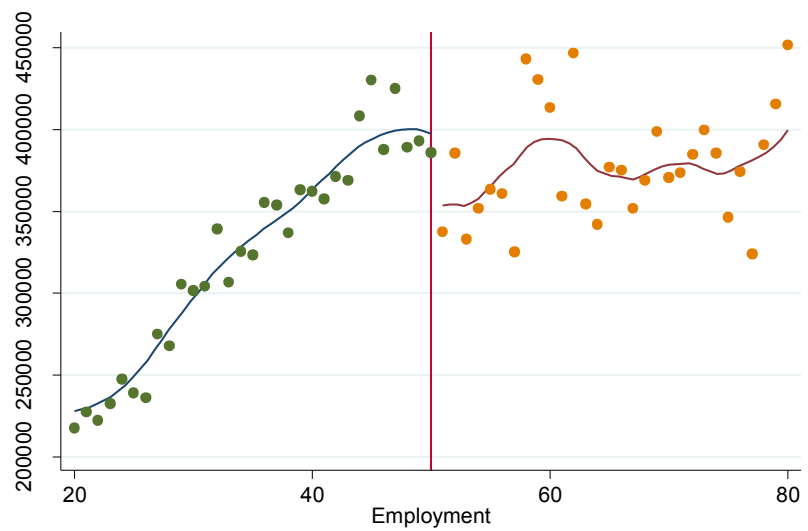

(B) Post-Treatment (2005-2007)

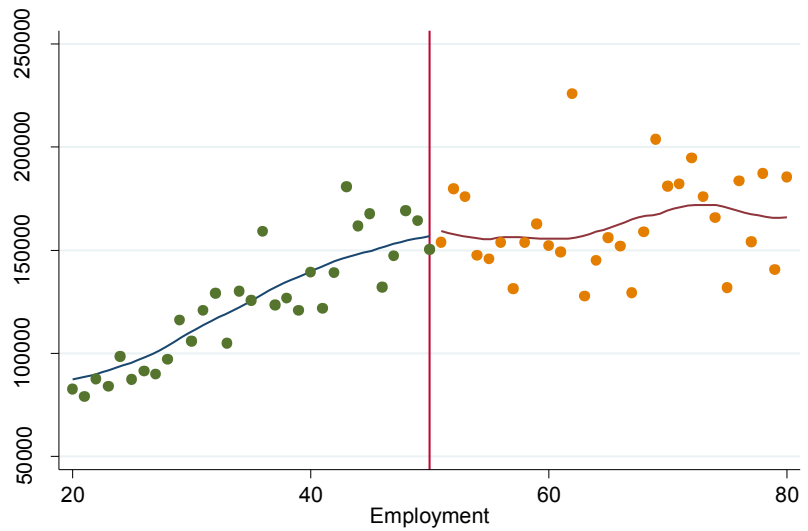

Notes: The figures plot average first-year tax allowances claimed by firm employment in British Pounds (GBP). Panel A pools the treatment period (2000-2004) while panel B pools the three years after the ICT tax incentive expired (2005-2007). The solid lines are locally weighted regressions based on the Stata command lowess.

the period 2000-2004 (treatment) as well as 2005-2007 (post-treatment). ${ }^{24}$ Panel A of Figure 4 illustrates a sizable discontinuity in tax allowance claims at the 50 employee threshold. In contrast, panel B of Figure 4 indicates no notable discontinuity at the 50 employee threshold after the incentive expired at the end of 2004. We view this as particularly convincing evidence of the success of the tax incentive, and of the validity of our research design. For instance, while firms' investment response to the tax incentive (estimated below) might be expected to spill over to some extent into the post-treatment period, the same cannot be said of firms' tax claims, and our finding of no effect in the post-treatment period is therefore reassuring.

While Figure 4 suggests that firms indeed responded to the tax incentive, at least in terms of their corporate tax filings, it is still possible that firms on either side of the threshold made similar investments in ICT over the period-i.e., it is possible that the incentive had no differential effect on actual ICT investment, but simply allowed those with 50 or fewer employees to claim allowances on investments they would have made even in the absence of the incentive. We therefore turn to evidence from the QCES, which reports quarterly investments in hardware and software by U.K. firms beginning in 2001. Panels A and B in Figure

\footnotetext{
${ }^{24}$ Note that we treat each firm-year as an observation. Aggregating each firm's investment over the period produces nearly identical results. We did not implement the Calonico et al. (2015) procedures for the HMRC dataset due to HMRC constraints. However, we experimented with a range of different functional forms as well as bandwidths around the policy cutoff. The results are robust to these modifications and are available upon request.
} 
Figure 5: ICT Investment by Firm-Level Employment

(A.1) Software: Treatment Period)

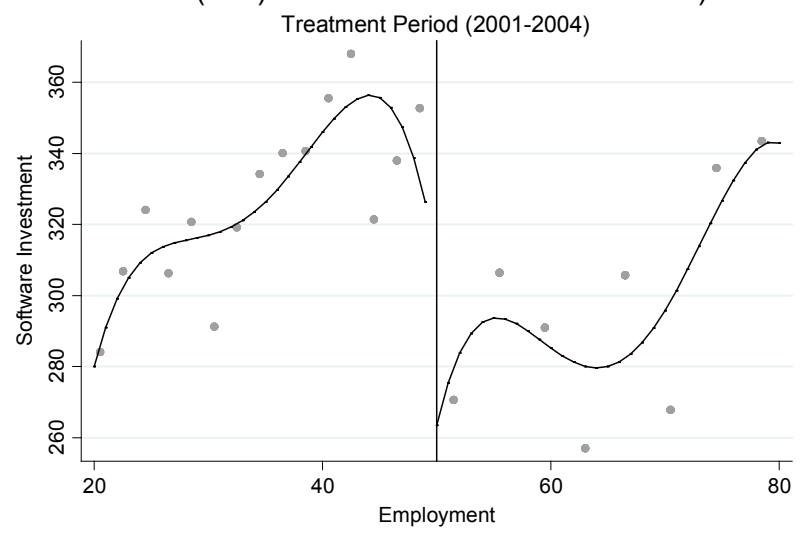

(B.1) Hardware: Treatment Period

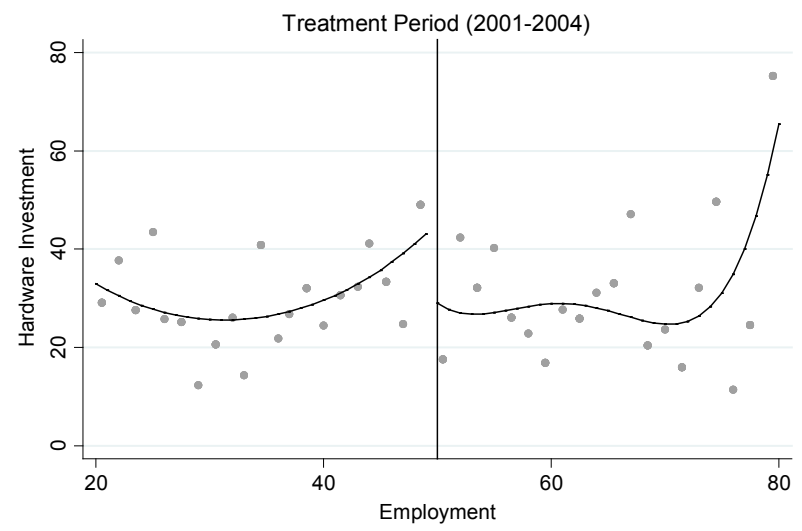

(A.2) Software: Post-Treatment Period

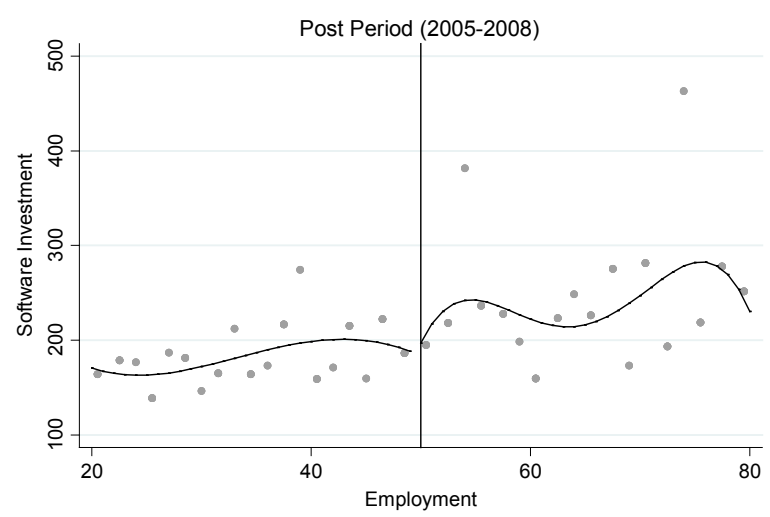

(B.2) Hardware: Post-Treatment Period

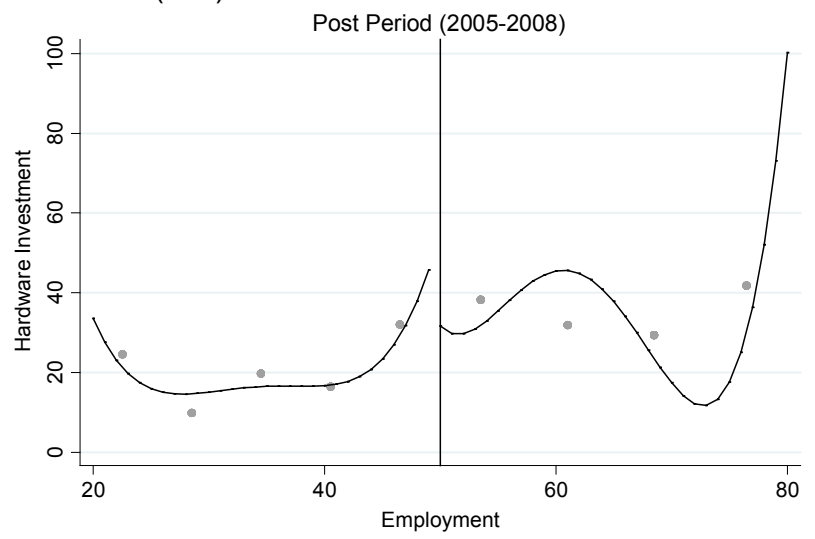

Notes: Panel A illustrates software investment along the firm size distribution for both the Treatment period (2001-2004, panel A.1) and the post-treatment period (2004-2008, panel A.2). Panel B shows analogous figures for hardware investment. For these figures we choose the optimal bandwidth and bin size to the left and the right of the 50 employee cutoff based on the methods described in Calonico et al. (2015). The lines are fitted fourth order polynomials. The graphs are based on the UK Quarterly Capital Expenditure Survey (QCES).

5 plot the average investment in software and hardware against employment for both the treatment period (2001-2004) as well as the post-treatment period (2005-2007). ${ }^{25}$ A clear discontinuity in investment for both capital types at 50 employees is visible for the treatment period but not for the post-treatment period. Note that the optimal number of bins and the bandwidth around the cutoff in these graphs was chosen according to the procedure from Calonico et al. (2015), which we describe in more detail in Section 3 above. ${ }^{26}$

\footnotetext{
${ }^{25}$ These data are not available for the pre-2000 period (nor 2000) so we cannot perform a falsification test during the pre-treatment period.

${ }^{26}$ To summarize, the procedure chooses the summary representation of the population regression function in the plots and the estimated regression functions in (1) following a data-driven procedure. Furthermore, since the regression function to the left of the
} 
Table 2: Discontinuity in ICT Investment at 50 Employees

\begin{tabular}{|c|c|c|c|c|c|c|}
\hline & \multicolumn{3}{|c|}{ A. Treatment: $2001-2004$} & \multicolumn{3}{|c|}{ B. Post Treatment: $2005-2007$} \\
\hline & (A.1) Softw. & (A.2) Hardw. & (A.3) Other & (B.1) Softw. & (B.2) Hardw. & (B.3) Other \\
\hline $\mathrm{RD}$ & $\begin{array}{c}-70.9158^{\star * *} \\
(24.2217)\end{array}$ & $\begin{array}{c}-13.2712^{* *} \\
(6.0726)\end{array}$ & $\begin{array}{c}14.5403 \\
(233.4556)\end{array}$ & $\begin{array}{c}27.6205 \\
(25.7599)\end{array}$ & $\begin{array}{c}10.442 \\
(9.5774)\end{array}$ & $\begin{array}{c}208.0195 \\
(153.9913)\end{array}$ \\
\hline Obs. & 75 & 81 & 107 & 75 & 123 & 81 \\
\hline Bandw. & 37 & 40 & 56 & 37 & 72 & 40 \\
\hline $\begin{array}{l}\text { Notes: } \\
\text { bias-cor } \\
\text { on softy } \\
\text { ing to C } \\
\text { errors b } \\
\text { levels a }\end{array}$ & $\begin{array}{l}\text { table report } \\
\text { ted procedu } \\
\text {, (2) hardwa } \\
\text { nico et al. (2 } \\
\text { d on Caloni } \\
\text { ndicated by }\end{array}$ & $\begin{array}{l}\text { ocal linear es } \\
\text { described in } \\
\text {, and (3) othe } \\
\text { 4) and the da } \\
\text { et al. }(2014) \\
<0.1,{ }^{* *} p<\end{array}$ & $\begin{array}{l}\text { nates of the } \\
\text { lonico et al. } \\
\text { capital invest } \\
\text { are aggrega } \\
\text { e reported in } \\
.05 \text {, and }{ }^{* * *}\end{array}$ & $\begin{array}{l}\text { ssion coeffici } \\
\text { The depen } \\
\text { the optime } \\
\text { the optimal f } \\
\text { theses belo } \\
01 \text {. }\end{array}$ & $\begin{array}{l}\text { it } \tau_{R D} \text { in mode } \\
\text { ent variables ar } \\
\text { bandwidth is d } \\
n \text {-size bin level } \\
\text { each coefficien }\end{array}$ & $\begin{array}{l}\text { (1) based on the } \\
\text { (1) expenditures } \\
\text { termined accord- } \\
\text { Robust standard } \\
\text { and significance }\end{array}$ \\
\hline
\end{tabular}

Panel A in Table 2 reports the associated local linear point estimates. ${ }^{27}$ These estimates indicate that the ICT incentive on average induced approximately $£ 71$ thousand in additional annual software investment and about $£ 13$ thousand in additional annual hardware investment for just-eligible firms relative to justnot-eligible firms. For both types of ICT investments, these effects correspond to roughly one half of a standard deviation in investment for eligible firms. ${ }^{28}$ Finally, we report a third category of ICT investment referred to as "other capital", which captures investments in non-ICT capital such as "fixtures/fittings, plant and machinery, etc.", according to the firm questionnaire. These investments were not eligible for the tax incentive and reassuringly we find no significant effect.

Panel B of Table 2 presents point estimates suggesting that, if anything, there was a relative underinvestment by small firms over the period 2005-2007. As noted above, it is not clear a priori whether we should expect the discontinuity in ICT investment to persist beyond the duration of the tax incentive, and the estimates in Table 2 indicate that in fact there was a subsequent fall in investment once the policy expired. This is consistent with firms' use of the tax incentive in order to manipulate the timing of planned investmentsi.e., it is consistent with "front-loading" of planned ICT expenditure. This is an interesting insight from a

cutoff is allowed to differ from that to the right, the representation of the population regression function in the plots and the optimal bandwidth are chosen separately on either side of the size threshold.

${ }^{27}$ Throughout the paper we only report the point estimates for the local linear specification with the optimal bandwidth based on Calonico et al. (2014). We experimented with a range of low order polynomials and also considered a range of different bandwidths. All results presented here are robust to these modifications.

${ }^{28}$ From Table 1 we see that the the standard deviation for software and hardware investment for eligible firms is, 151.11 and 23.61, respectively. Thus, the point estimates correspond to 0.47 and 0.56 standard deviations, respectively. 
policy perspective. To the extent that a tax incentive is designed to boost spending in "bad times", such a change in the timing of investments reflects precisely the intended effect of the policy. On the other hand, if the goal is to promote the use of ICT within small firms in order to foster long term productivity gains then a mere shift in the timing of pre-planned investments may be a less desirable outcome.

\subsection{The Short-Run Effect of ICT on Labor Demand within the Firm}

The finding of a positive effect of the tax incentive on ICT investment is perhaps not surprising, particularly considering that it took place during a period in which ICT was becoming increasingly important to day-to-day business operations in the U.K. In this section we go further and exploit the variation generated by these investments in order to estimate the short-run effect on hours worked and wages of workers employed in occupations with differing task content. Specifically, we use data from the ASHE and repeat the regression discontinuity approach from the previous sections with workers' weekly wages and weekly hours worked as the outcome variables of interest. ${ }^{29}$ To interpret these results we will then treat the ratio of the reduced form estimates presented in this section relative to the first-stage estimates reported above as an approximation to the local average treatment effect (LATE) of ICT investments on firm-level hours worked and wages-i.e. an approximate "implied IV estimate". ${ }^{30}$

As in the first stage above we begin with a graphical analysis. Figure 6 plots the average weekly wage and average weekly hours worked, as reported in the ASHE, along with QCES-reported labor productivity (turnover per worker). As usual these are each plotted against firm size. For earnings and hours worked we present results for the pre-treatment period $(1,1997-1999)$, the treatment period $(2,2001-2004)$ and the post-treatment period $(3,2005-2008)$. From the Figure we see that there are clear discontinuities for both the weekly wage and weekly hours worked during the treatment period (column 2) that are neither evident in the pre- nor the post-period (columns 1 and 2). Table 3 presents the corresponding local linear point

\footnotetext{
${ }^{29}$ Since our running variable is firm employment, it might at first seem as if any effect of the incentive on hours worked could potentially introduce endogeneity that could bias our results. In other words, the tax incentive itself may lead to employment growth, which may push marginal firms (those with 50 employees, for instance) over the tax incentive threshold. However, it is important to note that firms can only apply for the tax incentive once (it is a First Year Allowance). As a result, to the extent that the tax incentive induces growth in firm size, this can have no future effect on firm eligibility for the incentive.

${ }^{30}$ Imbens and Lemieux (2008) point out that the optimal bandwidth to be used in this exercise should be the bandwidth chosen for the outcome (reduced form) equation. Since the results in both instances (stages) are not overly sensitive to the choice of bandwidth we interpret the ratio of the estimates as being very near the true LATE.
} 
Figure 6: Average Earnings, Hours, \& Labor Productivity

(1) Pre-Treatment

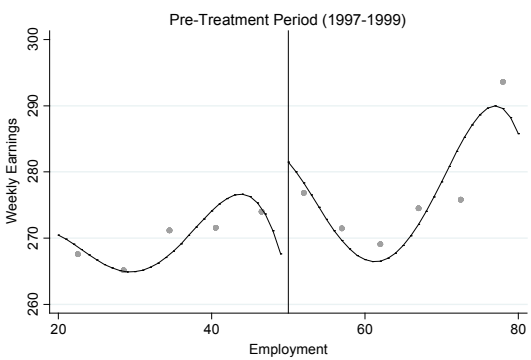

(1) Pre-Treatment

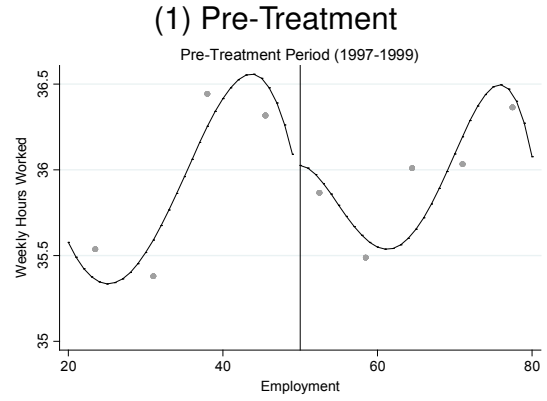

\section{A. Weekly Earnings}

(2) Treatment

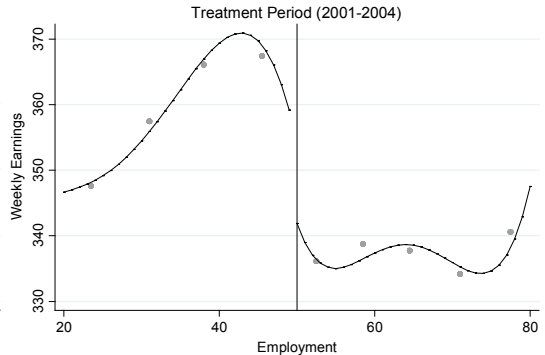

B. Weekly Hours

(2) Treatment
(3) Post-Treatment

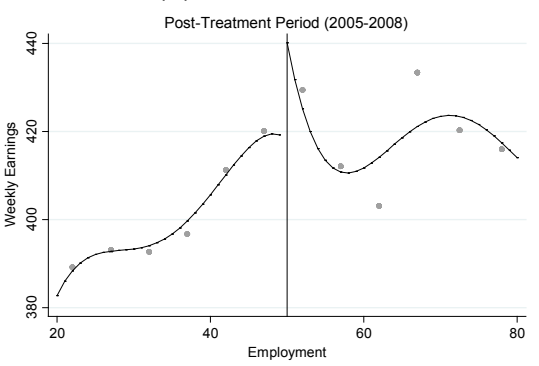

(3) Post-Treatment

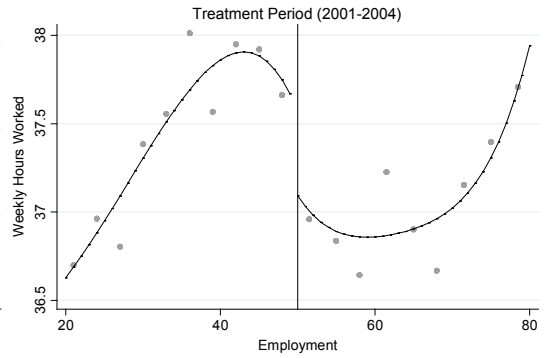

C. Labor Productivity

(2) Treatment
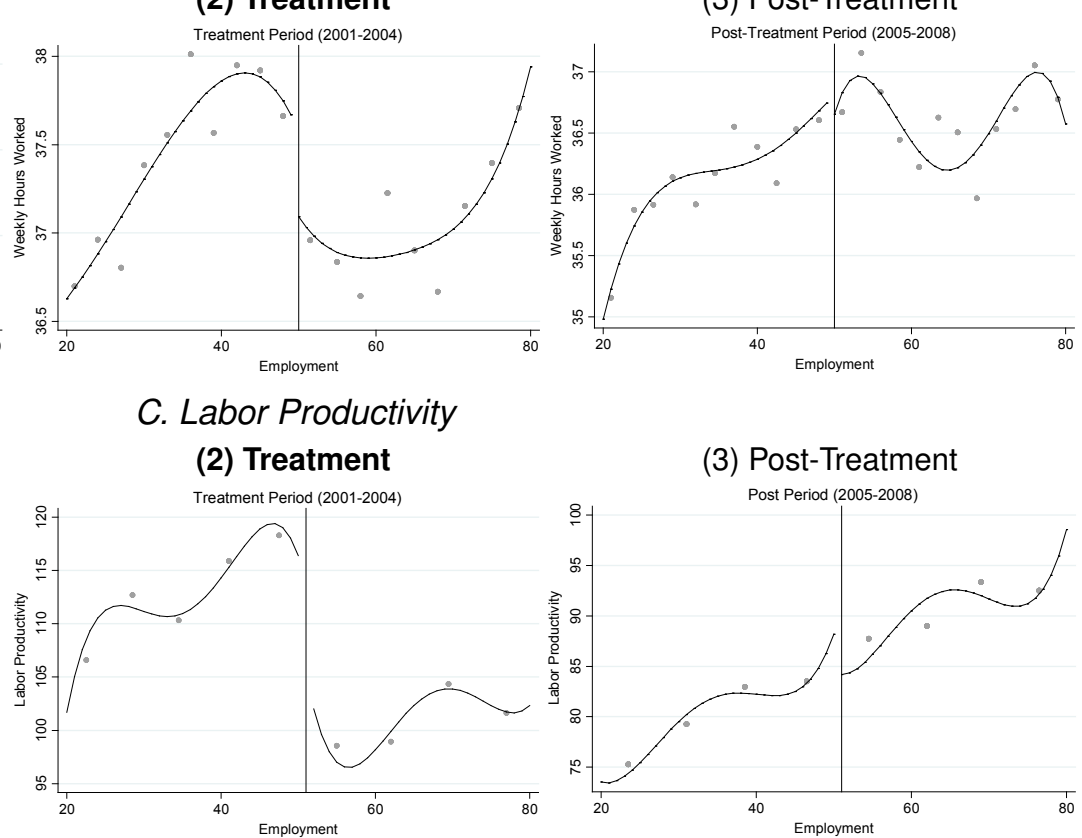

(3) Post-Treatment

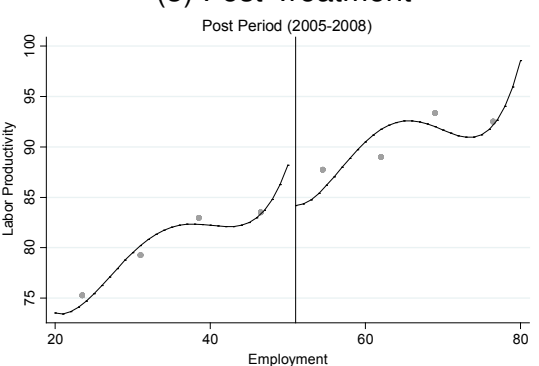

Notes: The figures display RD plots for the pre-treatment period (1, 1997-1999), the treatment period (2, 2001-2004) and the posttreatment period $(3,2005-2008)$. Panel A and B are based on the ASHE and display weekly earnings and hours, respectively. Panel C shows labor productivity (turnover per worker) drawn from the QCES. Our QCES sample starts in 2001 so we cannot report estimates for the pre-treatment period. Also, while we have ASHE data for 2000 we chose to display 2001-2004 for consistency with our QCES sample. The results don't materially change if we include 2000 and those graphs are available from the authors upon request. For all figures we choose the optimal bandwidth and bin size to the left and the right of the 50 employee cutoff based on the methods described in Calonico et al. (2015). The lines are fitted fourth order polynomials.

estimates.

To compute the "implied IV" estimate we divide each of the point estimates by 84.187 , corresponding to the sum of the first stage estimates for hardware and software. The resulting IV coefficient then reflects the causal effect of an additional thousand pounds of ICT investment on the outcomes of the average worker in 
Table 3: Discontinuity in Avg. Worker Outcomes

\begin{tabular}{|c|c|c|c|c|c|c|}
\hline & \multicolumn{3}{|c|}{ A. Treatment: 2001 - 2004} & \multicolumn{3}{|c|}{ B. Post Treatment: 2005-2008 } \\
\hline & (A.1) Earnings & (A.2) Hours & (A.3) Lab. Prod. & (A.1) Earnings & (A.2) Hours & (A.3) Lab. Prod. \\
\hline $\mathrm{RD}$ & $\begin{array}{c}-23.0448^{* \star *} \\
(4.5754)\end{array}$ & $\begin{array}{c}-0.8879^{\star \star *} \\
(0.2576)\end{array}$ & $\begin{array}{c}-11.3953^{* * *} \\
(3.4231)\end{array}$ & $\begin{array}{l}-4.6277 \\
(6.3052)\end{array}$ & $\begin{array}{l}-0.1901 \\
(0.2387)\end{array}$ & $\begin{array}{l}-0.2638 \\
(2.8218)\end{array}$ \\
\hline Obs. & 101 & 95 & 67 & 112 & 81 & 67 \\
\hline Bandw. & 50 & 47 & 33 & 61 & 40 & 33 \\
\hline
\end{tabular}

\footnotetext{
Notes: The table reports local linear estimates of the regression coefficient $\tau_{R D}$ in model (1) based on the bias-correction procedure described in Calonico et al. (2014). The dependent variables are (1) weekly earnings, (2) weekly hours from the ASHE, and (3) and labor productivity (turnover/worker) from the QCES. The optimal bandwidth is determined according to Calonico et al. (2014) and the data are aggregated to the optimal firm-size bin level. Robust standard errors based on Calonico et al. (2014) are reported in parentheses below each coefficient and significance levels are indicated by ${ }^{*} p<0.1,{ }^{* *} p<0.05$, and ${ }^{* \star *} p<0.01$.
}

the firm. Multiplying this number by 50 we then obtain the estimated outcomes for an expenditure of $£ 1000$ on each worker in a firm with 50 employees (constituting, for example, one new computer plus software and accessories). Our estimates suggest that such an investment results in an approximate $£ 14$ increase in weekly earnings and about an extra half hour of work per week, on average per worker.

Overall, these firm-level effects suggest that ICT investment induces additional employment and higher wages, on average, within the investing firms. One interpretation of these results is that there are sizable productivity gains associated with the adoption of ICT technologies, which partly accrue to workers within these firms. Indeed, RD estimates with respect to QCES-reported labor productivity reveal a sizable discontinuity in labor productivity (turnover per worker) during the treatment period but not after (see columns A.3 and B.3 in Table 3).

We devote the remainder of this section to investigate the extent to which these productivity gains accrued to workers performing different workplace tasks. To this end, we estimate the effect of the policy on workers within the four broad occupation groups defined in Acemoglu and Autor (2011): (1) managerial, professional and technical occupations; (2) sales, clerical and administrative support; (3) production, craft, repair and operative occupations; and (4) service occupations. As these authors argue, that these categories are broadly representative of different sets of production tasks, namely (1) non-routine cognitive tasks; (2) routine cognitive tasks; (3) routine manual tasks; and (4) non-routine manual tasks, respectively. As noted in the introduction, several studies support the idea that this classification of occupations reflects important dimensions of computer-worker interaction. 
Figure 7: Weekly Earnings: Routine, Non-Routine, Cognitive \& Manual Jobs

\section{A. Non-Routine Cognitive}

(1) Pre-Treatment

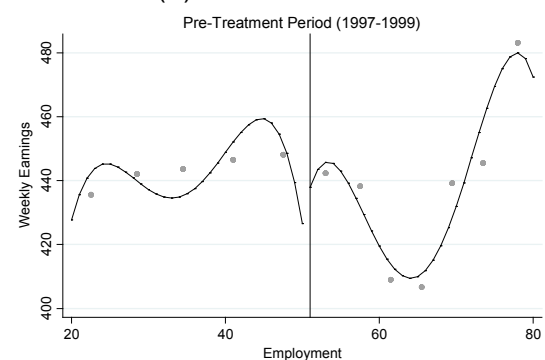

(1) Pre-Treatment

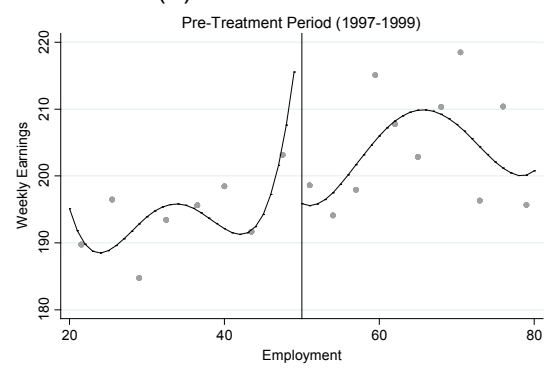

(1) Pre-Treatment

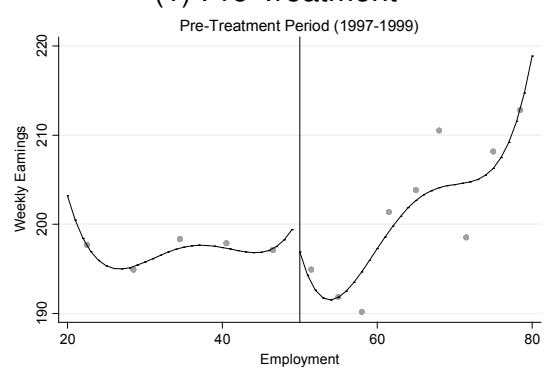

(1) Pre-Treatment

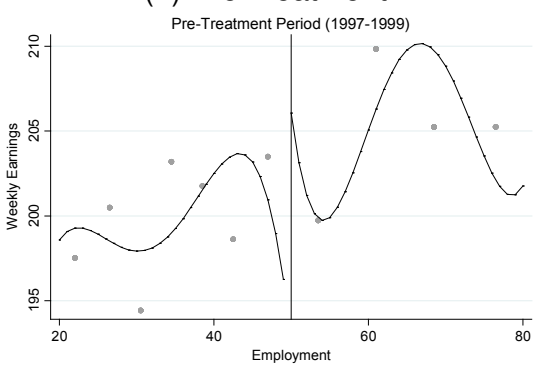

(2) Treatment

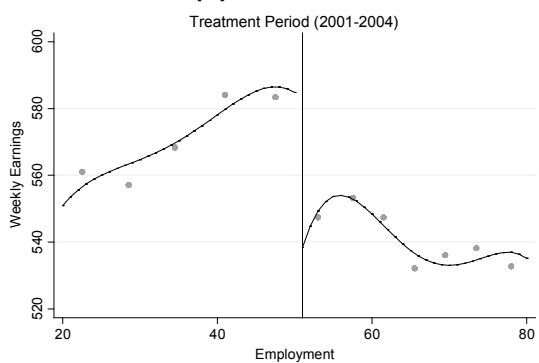

B. Routine Cognitive

(2) Treatment

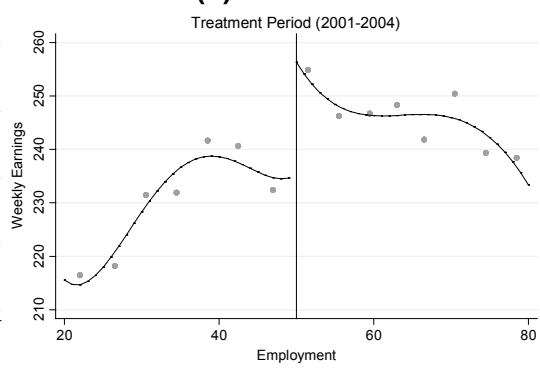

C. Non-Routine Manual

(2) Treatment

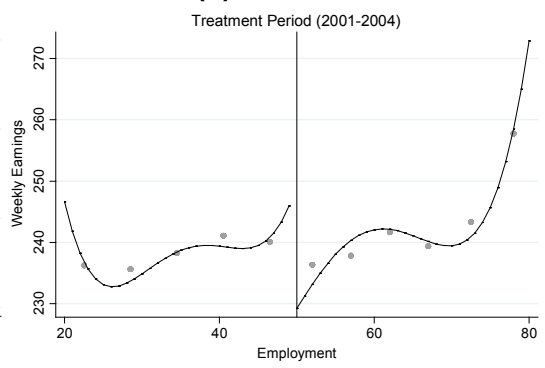

D. Routine Manual

(2) Treatment

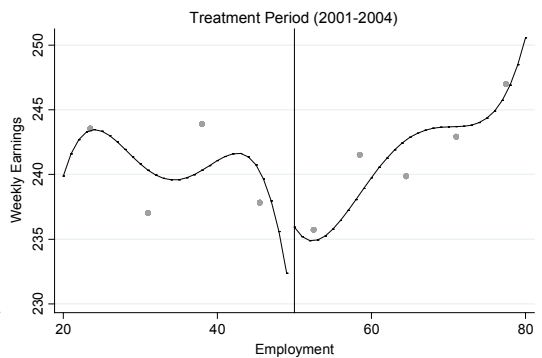

(3) Post-Treatment

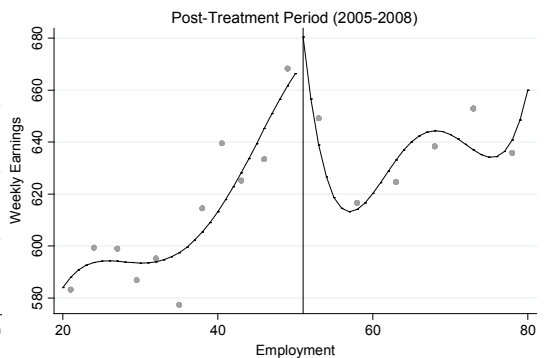

(3) Post-Treatment

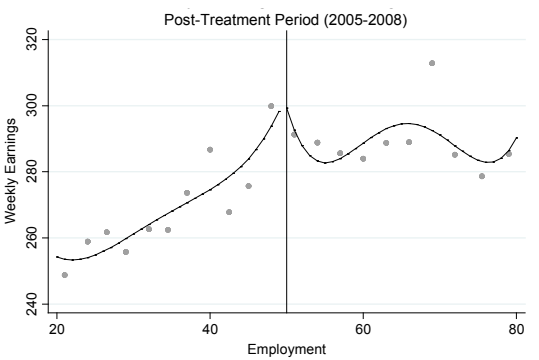

(3) Post-Treatment

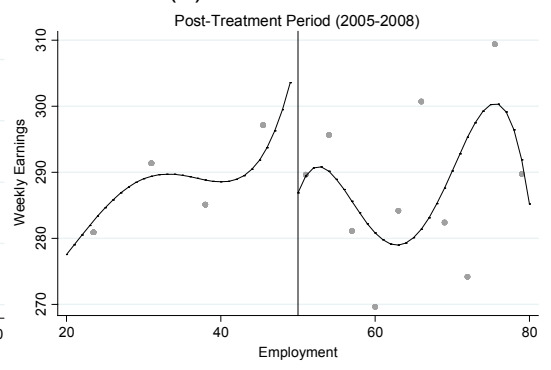

(3) Post-Treatment

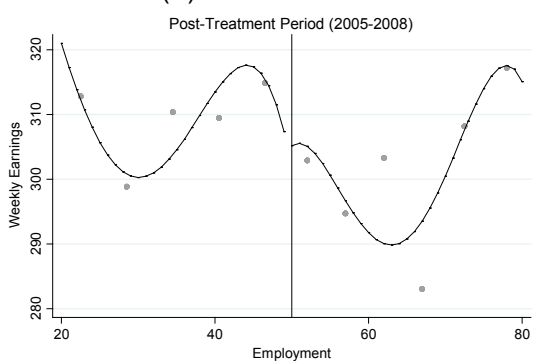

Notes: The figures decompose the earnings results from Figure 6 into the four occupation groups defined in Acemoglu and Autor (2011): non-routine cognitive (panel A), routine cognitive (panel B), non-routine manual (panel C), and routine manual (panel D). For all figures we choose the optimal bandwidth and bin size to the left and the right of the 50 employee cutoff based on the methods described in Calonico et al. (2015). The lines are fitted fourth order polynomials. 
Figure 8: Weekly Hours: Routine, Non-Routine, Cognitive \& Manual Jobs

(1) Pre-Treatment

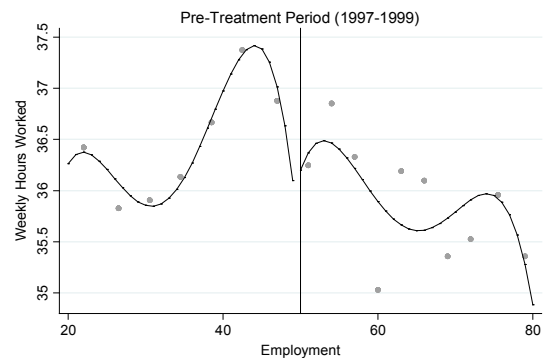

(1) Pre-Treatment

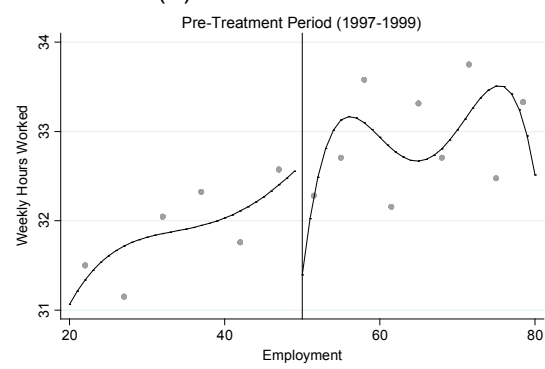

(1) Pre-Treatment

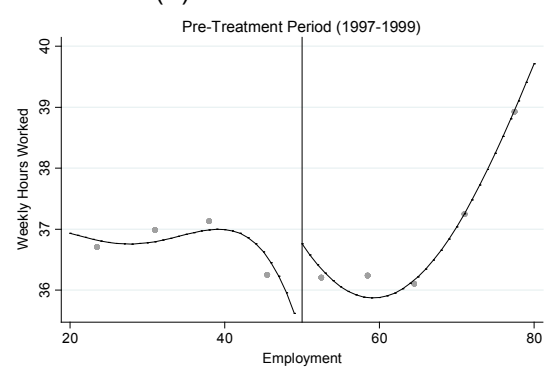

(1) Pre-Treatment

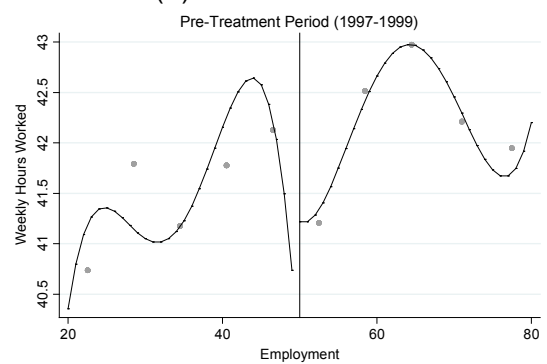

A. Non-Routine Cognitive

(2) Treatment

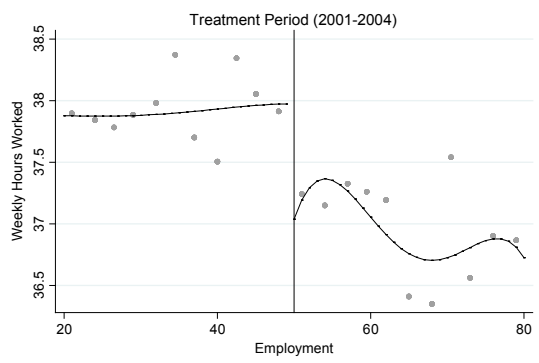

B. Routine Cognitive

(2) Treatment

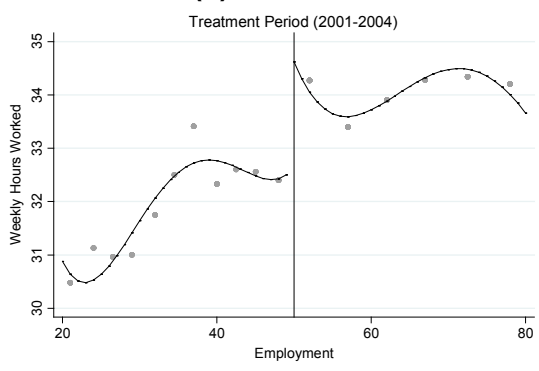

C. Non-Routine Manual

(2) Treatment

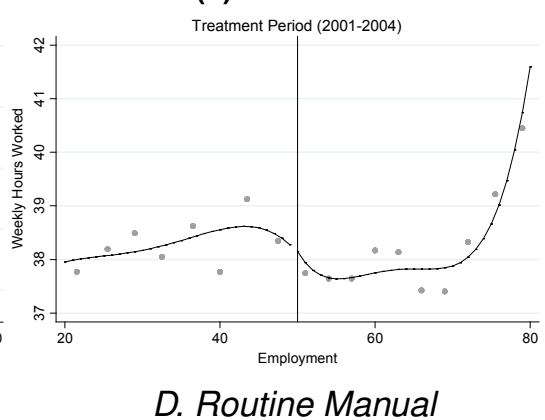

(2) Treatment

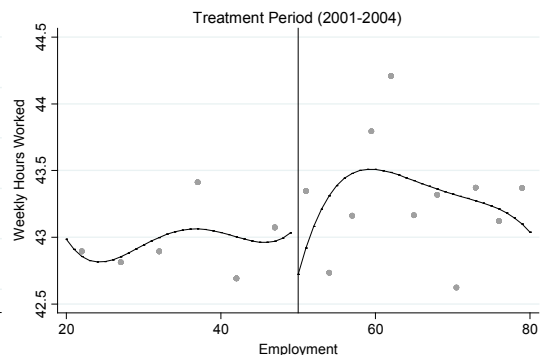

(3) Post-Treatment

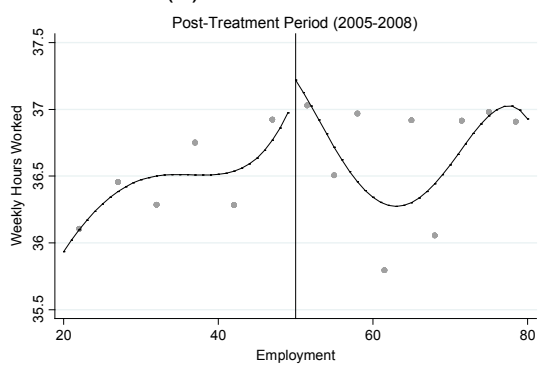

(3) Post-Treatment

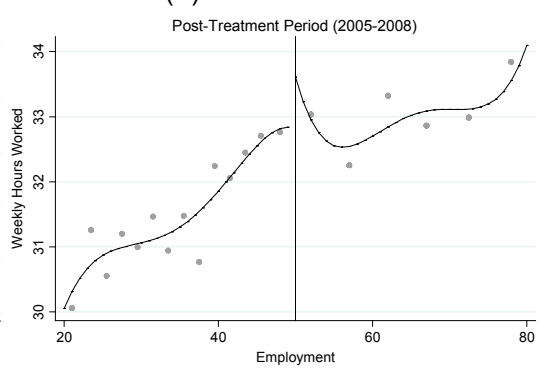

(3) Post-Treatment

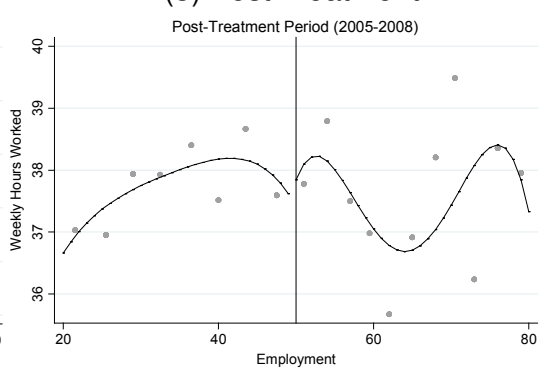

(3) Post-Treatment

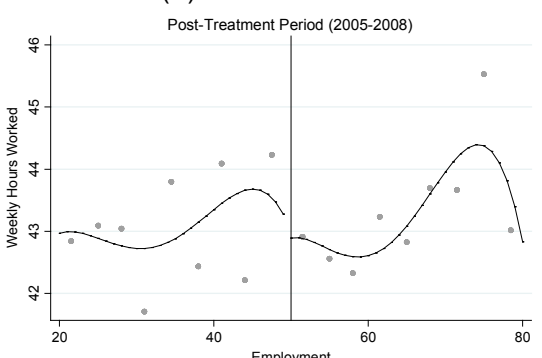

Notes: The figures decompose the results on weekly hours from Figure 6 into the four occupation groups defined in Acemoglu and Autor (2011): non-routine cognitive (panel A), routine cognitive (panel B), non-routine manual (panel C), and routine manual (panel D). For all figures we choose the optimal bandwidth and bin size to the left and the right of the 50 employee cutoff based on the methods described in Calonico et al. (2015). The lines are fitted fourth order polynomials. 
Our estimates suggest that the overall gains in both hours worked and wages, as reflected in the estimates in Table 3, were by no means evenly shared across groups of workers performing fundamentally different tasks. In particular, Figures 7 and 8 as well as Table 4 indicate that the largest impact of the tax incentive was on cognitive workers, with little evidence of an impact on manual workers. The latter finding appears plausible, given that manual work (such as child care or manual construction work) is not likely to be strongly complementary to nor substitutable with ICT and will therefore only be indirectly affected by ICT investments, presumably in the long run (e.g., Autor and Dorn, 2013). Taken together, and if we assume that the relative supply of task types over this period was fixed, these results then imply a significant outward shift of the demand for non-routine, cognitive tasks and a simultaneous, but less pronounced, inward shift in the demand for routine, cognitive tasks.

Again, the economic magnitudes are also important. Repeating the thought experiment from above, an extra $£ 50$ thousand of ICT investment for a firm with 50 employees (again $£ 1000$ for each worker) induced an earnings increase of approximately $£ 25$ per week for the average non-routine cognitive worker while earnings of the average routine cognitive worker decreased by approximately $£ 5$ per week. ${ }^{31}$

Thus, the gains by non-routine cognitive workers are about five times as large as the losses by routine cognitive workers, consistent with the net positive effect on the average earnings in the firm (see Table 3). Similarly, this investment induces an approximate 20 minute increase in the average weekly hours for non-routine cognitive workers and about an equal decrease in hours worked by routine cognitive workers. Note, however, that these average results do not allow us to disentangle hiring and firing decisions from the reallocation of existing workers to new tasks within the firm. That is, these average effects on hours and wages may result either from hiring non-routine cognitive workers and firing routine cognitive workers, or else from promoting a formerly routine cognitive worker to a new job in which she performs primarily non-routine cognitive tasks.

Given the aggregate nature of these occupation groups, we next explore the impact of the policy on wage dispersion within each occupation group, results that we will return to later in our comparison of competing models of ICT adoption. Specifically, we focus on the difference between the log wage at the 90th percentile

\footnotetext{
${ }^{31}$ Again, this implied IV estimate results from dividing the point estimate by 84.187 (the first stage effect on total ICT investment) and then multiplying by 50 .
} 
Table 4: Discontinuity in Worker Outcomes: Routine, Non-Routine, Cognitive \& Manual

\begin{tabular}{|c|c|c|c|c|c|c|c|c|c|}
\hline & \multicolumn{3}{|c|}{ A. Pre-Treat.: 1997 - 1999} & \multicolumn{3}{|c|}{ B. Treatment: 2001 - 2004} & \multicolumn{3}{|c|}{ C. Post Treat.: $2005-2008$} \\
\hline & $(A .1)$ & (A.2) & (A.3) & (B.1) & (B.2) & (B.3) & (C.1) & (C.2) & (C.3) \\
\hline & $\begin{array}{l}\text { Earn- } \\
\text { ings }\end{array}$ & Hours & $\begin{array}{l}\text { Wage } \\
\text { Disp. }\end{array}$ & $\begin{array}{l}\text { Earn- } \\
\text { ings }\end{array}$ & Hours & $\begin{array}{l}\text { Wage } \\
\text { Disp. }\end{array}$ & $\begin{array}{l}\text { Earn- } \\
\text { ings }\end{array}$ & Hours & $\begin{array}{l}\text { Wage } \\
\text { Disp. }\end{array}$ \\
\hline \multicolumn{10}{|c|}{ A. Non-Routine Cognitive } \\
\hline $\begin{array}{l}\text { RD Estimate } \\
\text { Std. Err. }\end{array}$ & $\begin{array}{l}-10.61 \\
(10.4)\end{array}$ & $\begin{array}{l}-0.46 \\
(0.35)\end{array}$ & $\begin{array}{l}-0.51 \\
(0.91)\end{array}$ & $\begin{array}{c}-42.3821^{\star \star \star} \\
(11.6154)\end{array}$ & 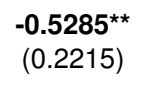 & $\begin{array}{l}-0.341^{\star *} \\
(0.1611)\end{array}$ & $\begin{array}{c}-8.9 \\
(14.1)\end{array}$ & $\begin{array}{l}-0.14 \\
(0.29)\end{array}$ & $\begin{array}{l}-0.83 \\
(0.69)\end{array}$ \\
\hline Obs. & 110 & 109 & 95 & 114 & 117 & 114 & 115 & 106 & 117 \\
\hline Bandwidth & 59 & 58 & 47 & 63 & 66 & 63 & 64 & 55 & 66 \\
\hline \multicolumn{10}{|c|}{ B. Routine Cognitive } \\
\hline $\begin{array}{l}\text { RD Estimate } \\
\text { Std. Err. }\end{array}$ & $\begin{array}{r}-1.33 \\
(4.9)\end{array}$ & $\begin{array}{c}0.38 \\
(0.49)\end{array}$ & $\begin{array}{l}-0.28 \\
(0.34)\end{array}$ & $\begin{array}{l}8.6142 * \\
(4.797)\end{array}$ & $\begin{array}{l}0.5259^{\star} \\
(0.307)\end{array}$ & $\begin{array}{c}0.2412^{*} \\
(0.1693)\end{array}$ & $\begin{array}{l}-4.02 \\
(6.99)\end{array}$ & $\begin{array}{l}-0.27 \\
(0.34)\end{array}$ & $\begin{array}{l}-0.44 \\
(0.45)\end{array}$ \\
\hline Obs. & 111 & 112 & 112 & 95 & 93 & 95 & 113 & 95 & 95 \\
\hline Bandwidth & 60 & 61 & 61 & 47 & 46 & 47 & 62 & 47 & 47 \\
\hline \multicolumn{10}{|c|}{ C. Non-Routine Manual } \\
\hline $\begin{array}{l}\text { RD Estimate } \\
\text { Std. Err. }\end{array}$ & $\begin{array}{c}5.35 \\
(4.16)\end{array}$ & $\begin{array}{c}0.49 \\
(0.49)\end{array}$ & $\begin{array}{c}0.62 \\
(0.73)\end{array}$ & $\begin{array}{l}-4.5329 \\
(4.3347)\end{array}$ & $\begin{array}{c}-0.247 \\
(0.3536)\end{array}$ & $\begin{array}{c}0.4123 \\
(0.3834)\end{array}$ & $\begin{array}{l}-8.12 \\
(6.38)\end{array}$ & $\begin{array}{c}0.45 \\
(0.55)\end{array}$ & $\begin{array}{c}0.57 \\
(0.56)\end{array}$ \\
\hline Obs. & 128 & 114 & 111 & 110 & 107 & 112 & 436 & 332 & 114 \\
\hline Bandwidth & 77 & 63 & 60 & 59 & 56 & 61 & 58 & 41 & 63 \\
\hline \multicolumn{10}{|c|}{ D. Routine Manual } \\
\hline $\begin{array}{l}\text { RD Estimate } \\
\text { Std. Err. }\end{array}$ & $\begin{array}{c}5.99 \\
(3.81)\end{array}$ & $\begin{array}{l}-0.12 \\
(0.16)\end{array}$ & $\begin{array}{c}0.35 \\
(0.48)\end{array}$ & $\begin{array}{c}6.3721 \\
(4.7223)\end{array}$ & $\begin{array}{c}0.1107 \\
(0.5353)\end{array}$ & $\begin{array}{c}\mathbf{0 . 5 3 4 3} \\
(0.4809)\end{array}$ & $\begin{array}{l}-2.97 \\
(4.92)\end{array}$ & $\begin{array}{c}0.17 \\
(0.53)\end{array}$ & $\begin{array}{c}0.7 \\
(0.84)\end{array}$ \\
\hline Obs. & 115 & 120 & 105 & 116 & 111 & 105 & 116 & 105 & 116 \\
\hline Bandwidth & 64 & 69 & 54 & 65 & 60 & 54 & 65 & 54 & 65 \\
\hline
\end{tabular}

of the wage distribution and the log wage at the 10th percentile (the so-called 90-10 gap) within each of the four occupation groups. Column 3 in each panel of Table 4 reports the estimated second stage effects while the associated plots are displayed in Figure 9. The results suggest an overall rise in wage inequality for non-routine, cognitive work as well as a decline in wage inequality for routine, cognitive work that is only borderline statistically significant. There is no evident effect within manual occupations. Thus, the ICT investments not only increased the average return to non-routine, cognitive work but also increased the gap between the most and least productive workers. In contrast, the decline in the average return to routine, $\operatorname{cog}$ - 
Figure 9: Wage Dispersion: Routine, Non-Routine, Cognitive \& Manual Jobs

\section{A. Non-Routine Cognitive}

(1) Pre-Treatment

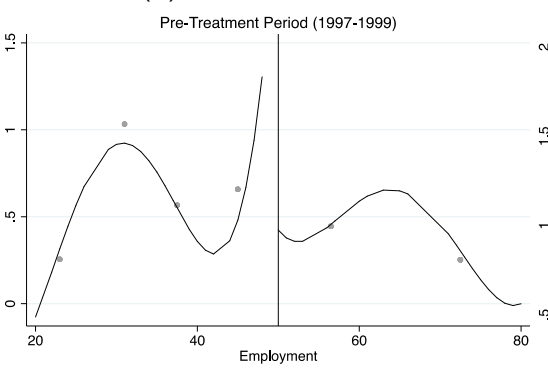

(1) Pre-Treatment

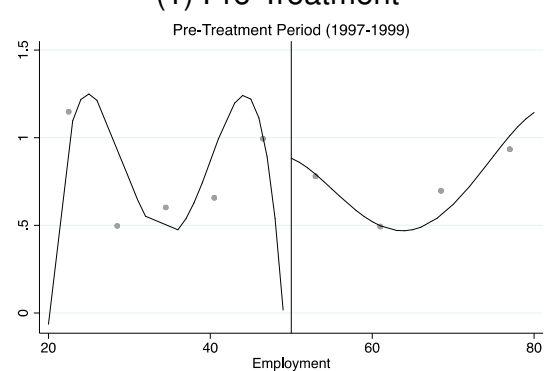

(1) Pre-Treatment

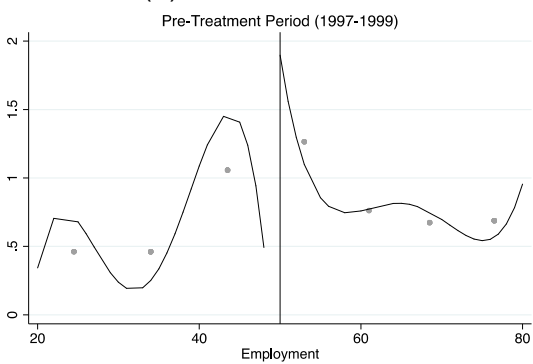

Employment

(1) Pre-Treatment

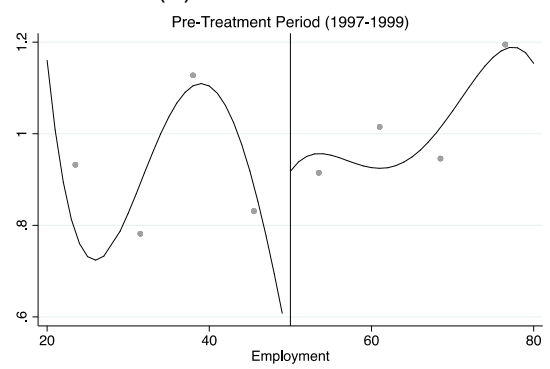

(2) Treatment

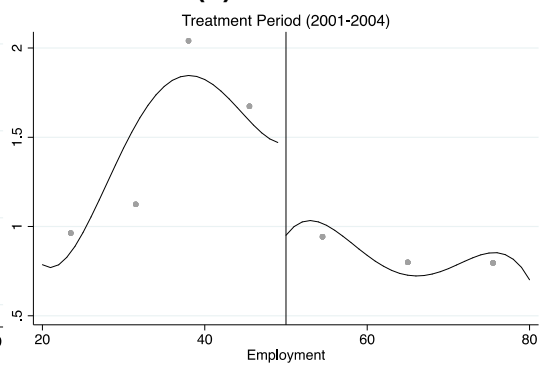

B. Routine Cognitive

(2) Treatment
(3) Post-Treatment

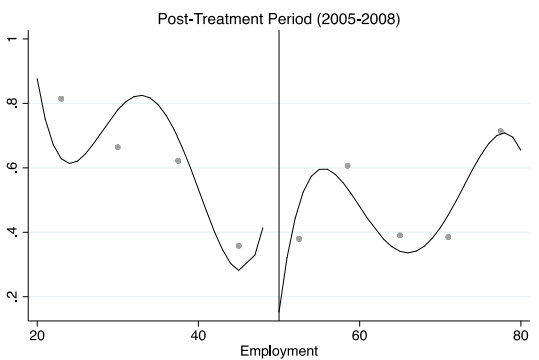

(3) Post-Treatment

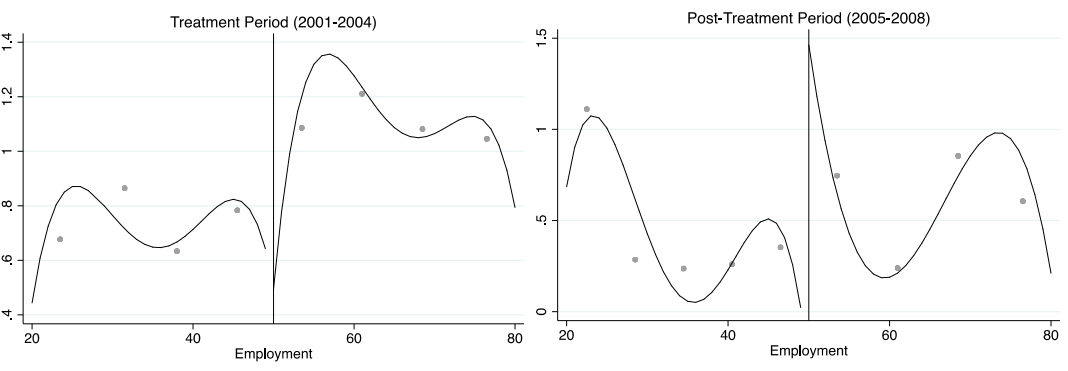

C. Non-Routine Manual

(2) Treatment

(3) Post-Treatment

Treatment Period (2001-2004)
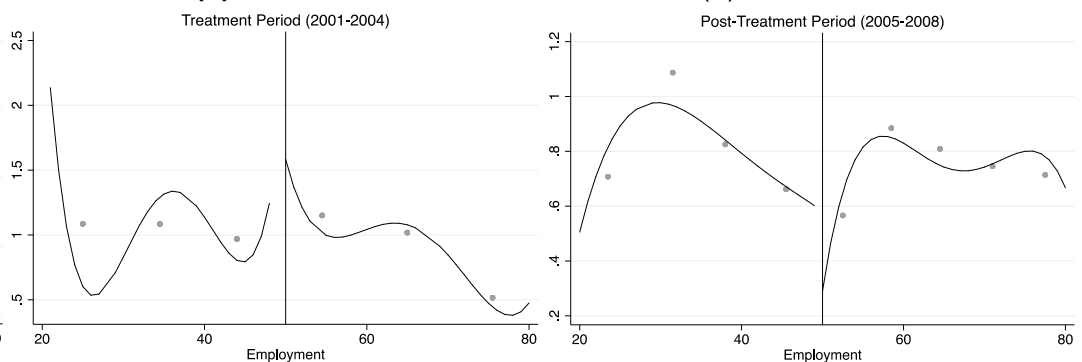

D. Routine Manual

(2) Treatment
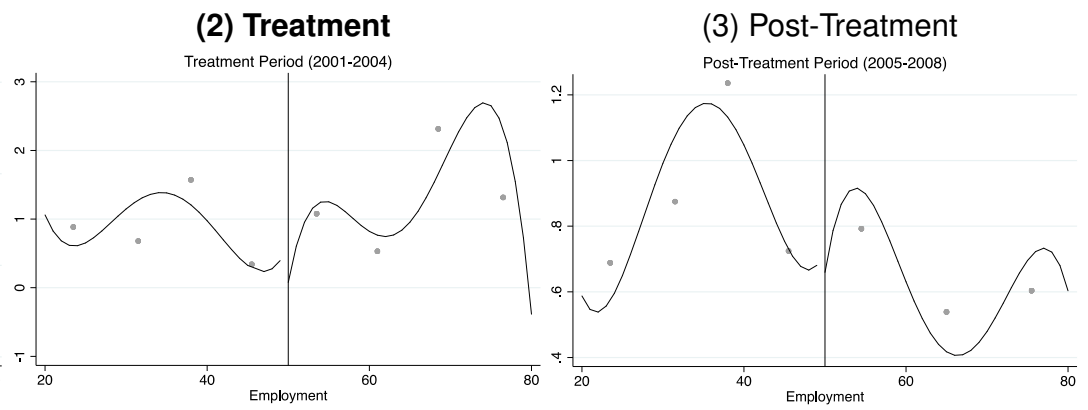

(3) Post-Treatment

Notes: The figures are constructed as in Figure 6 and report the log wage gap between the 90th and 10th percentile of the earnings distribution within each of the the four occupation groups defined in Acemoglu and Autor (2011): non-routine cognitive (panel A), routine cognitive (panel B), non-routine manual (panel C), and routine manual (panel D). For all figures we choose the optimal bandwidth and bin size to the left and the right of the 50 employee cutoff based on the methods described in Calonico et al. (2015). The lines are fitted fourth order polynomials. 
nitive work was possibly associated with relative gains for the least productive workers.

\subsection{Organizational Response to ICT Adoption}

One potential explanation for the seemingly large effects on worker outcomes and labor productivity is the possibility of concurrent organizational change. While it is thought to be an important complement to the ICT-adoption process there is little evidence on the relative timing of organizational changes and technology adoption. For instance, it may be that firms make singular investments in new technologies and then integrate those technologies over a period of time in conjunction with incremental changes to the organization. Alternatively, organizational changes may be planned explicitly in order to coincide with ICT investments, and may therefore be enacted over a short horizon. In this case, a fall in the effective price of ICT may induce firms to immediately restructure their workforce in favor of ICT-complementary workers, both directly through hiring and firing as well as via other types of restructuring.

In this section we address the magnitude and timing of organizational changes with respect to ICT investment. Specifically, we present regression discontinuity results for firm responses to the following question in the U.K. Innovation Survey: "Did your enterprise make major changes in the following areas of business structure and practices during the three-year period, 2002-2004?" There are four aspects of business strategy addressed, for which firms could simply answer yes or no. These are: "New or significantly changed corporate strategy", "Implementation of advanced management techniques", "Implementation of major changes to your organizational structure", and "Implementation of changes in marketing concepts or strategies". We report summary statistics for the fraction of firms responding yes in panel D of Table 1.

We repeat the RD strategy from the previous sections, where now the variable of interest is the share of firms who responded "yes" to each question. Figure 10 and the point estimates in Table 5 suggest that the tax policy indeed led firms to implement advanced management techniques and to otherwise make changes to their organizational structure, while there is little evidence for the other channels. Since any discontinuity during the treatment period can be interpreted as a causal consequence of ICT investment, this suggests that ICT adoption, changes in organizational structure, and changes in management practices are indeed both contemporaneous and complementary, a result that perhaps goes some way toward explaining the observed wage and employment effects. Furthermore, in light of the labor demand response described above, the res- 
Figure 10: ICT Adoption \& Organizational Change

A. Adopt New Corporate Structure

(1) Treatment

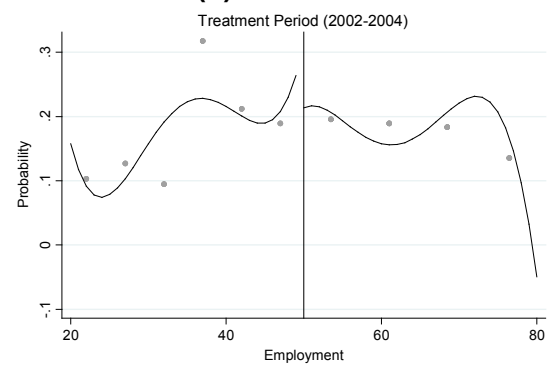

B. Adopt Advanced Management Practices

(1) Treatment
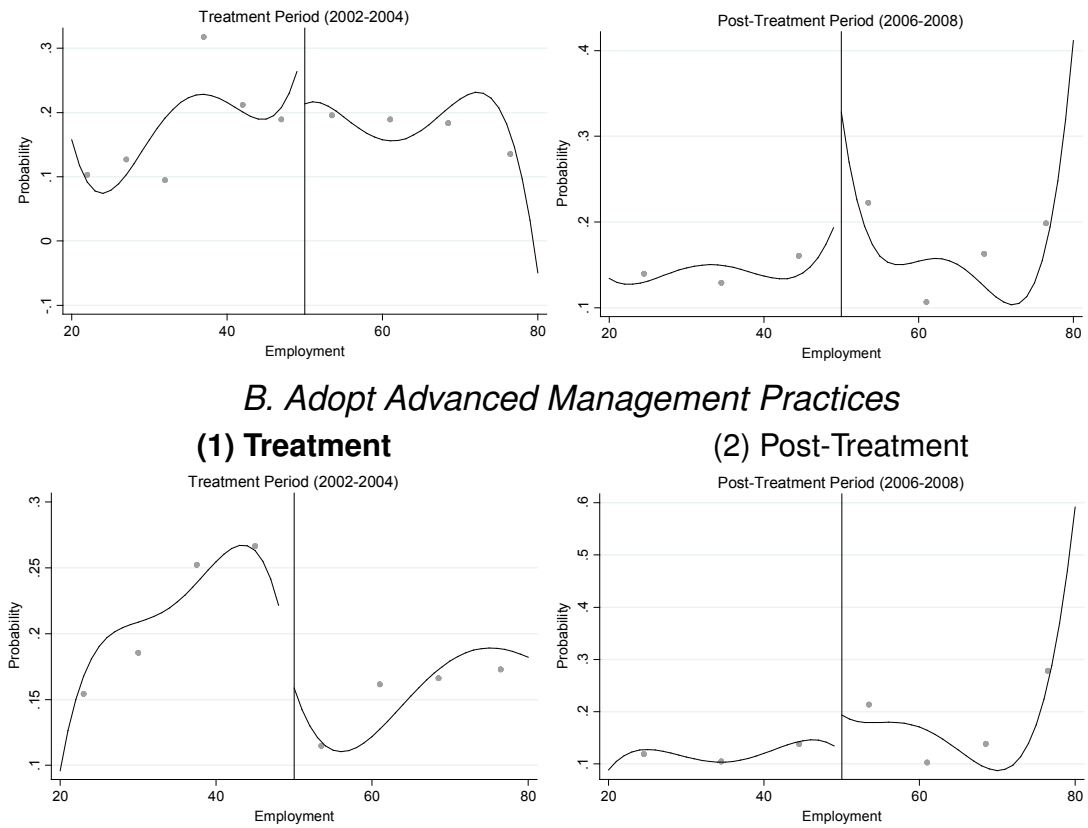

(2) Post-Treatment

(2) Post-Treatment

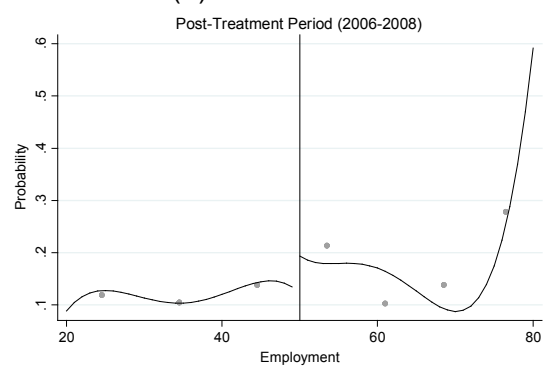

C. Change in Organizational Structure

(1) Treatment

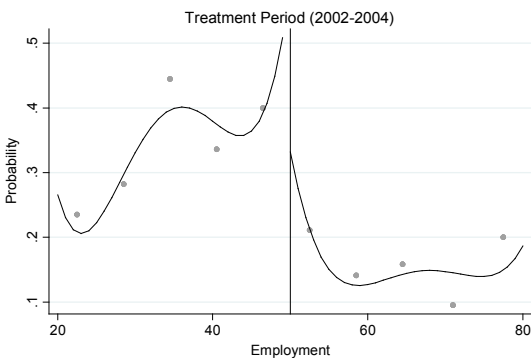

(2) Post-Treatment

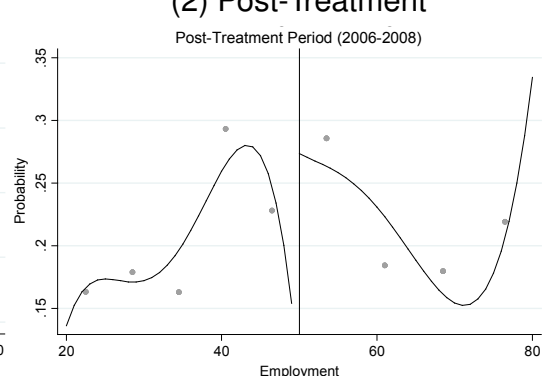

D. Change in Marketing Practices

\section{(1) Treatment}

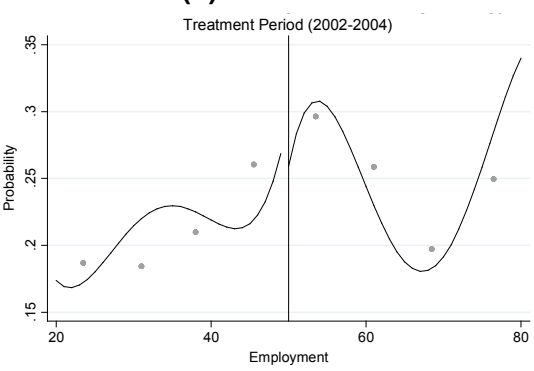

(2) Post-Treatment

Post-Treatment Period (2006-2008)

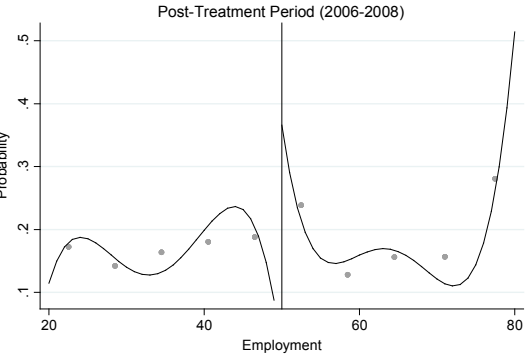

Notes: The figures are constructed as in Figure 6 and report the fraction of firms conducting four types of organizational changes based on the CIS. Column (1) presents estimates for the series of questions pertaining to the period 2002-2004 (treatment) and column (2) covers the period 2006-2008 (post-treatment). For all figures we choose the optimal bandwidth and bin size to the left and the right of the 50 employee cutoff based on the methods described in Calonico et al. (2015). The lines are fitted fourth order polynomials. 
Table 5: ICT Adoption \& Organizational Change

\begin{tabular}{|c|c|c|c|c|c|c|c|c|}
\hline & \multicolumn{4}{|c|}{ A. Treatment: 2002 - 2004} & \multicolumn{4}{|c|}{ B. Post Treatment: $2006-2008$} \\
\hline & $(\mathrm{A} .1)$ & (A.2) & (A.3) & (A.4) & (A.1) & (A.2) & (A.3) & (A.4) \\
\hline & $\begin{array}{l}\text { Corp. } \\
\text { Strat. }\end{array}$ & $\begin{array}{l}\text { Man. } \\
\text { Tech. }\end{array}$ & $\begin{array}{l}\text { Org. } \\
\text { Struc. }\end{array}$ & $\begin{array}{c}\text { Market- } \\
\text { ing }\end{array}$ & $\begin{array}{l}\text { Corp. } \\
\text { Strat. }\end{array}$ & $\begin{array}{l}\text { Man. } \\
\text { Tech. }\end{array}$ & $\begin{array}{l}\text { Org. } \\
\text { Struc. }\end{array}$ & $\begin{array}{c}\text { Market- } \\
\text { ing }\end{array}$ \\
\hline RD Estimate & -0.0316 & $-0.0661^{* *}$ & $-0.1773^{* * *}$ & 0.0307 & 0.0386 & 0.0157 & -0.0138 & 0.0051 \\
\hline & 0.0654 & 0.0331 & 0.0629 & 0.0714 & 0.0493 & 0.0549 & 0.0769 & 0.0529 \\
\hline Obs. & 85 & 79 & 79 & 79 & 84 & 88 & 84 & 87 \\
\hline Bandw. & 42 & 39 & 39 & 39 & 42 & 47 & 42 & 45 \\
\hline
\end{tabular}

Notes: The table reports local linear estimates of the regression coefficient $\tau_{R D}$ in model (1) based on the biascorrection procedure described in Calonico et al. (2014). The data are taken from two waves of the CIS. The dependent variables are indicator variables equal to one if a firm reports to have (1) implemented a change to its corporate structure, (2) adopted new advanced management techniques, (3) implemented changes in the organizational structure, or (4) changed its marketing practices. Panel A reports results for the series of questions covering the period 2002-2004 while panel B covers the period 2006-2008. The optimal bandwidth is determined according to Calonico et al. (2014) and the data are aggregated to the optimal firm-size bin level. Robust standard errors based on Calonico et al. (2014) are reported in parentheses below each coefficient and significance levels are indicated by ${ }^{*} p<0.1,{ }^{* *} p<0.05$, and ${ }^{* \star *} p<0.01$.

ults effectively confirm the non-routine, cognitive bias of organizational change. ${ }^{32}$

\section{Evidence on Competing Models of ICT Adoption}

The link between ICT investments and labor demand within the firm is illuminated by the finding of a role for organizational change. However, mapping the observed effects to a specific economic model is not straightforward. Recently, two models have been proposed to explain the potential impact of ICT adoption on firm organization and labor demand. First is the tasks-based model, a framework that was most recently extended by Acemoglu and Autor (2011) in order to endogenize the assignment of tasks to skill. In the context of this model, the results are consistent with complementarity between ICT and non-routine, cognitive tasks, such that new computer technologies simply augment the workplace productivity of the existing highskill workers who perform these tasks. At the same time, routine, cognitive tasks may be straightforwardly replaced by ICT - for instance, many types of back-office work may be subsequently replaced by computer software. Furthermore, as the Acemoglu and Autor (2011) model highlights, the increased demand for nonroutine, cognitive work may draw in relatively less-productive workers who formerly performed different tasks, and this may increase wage inequality among non-routine, cognitive workers. To the extent that these

\footnotetext{
${ }^{32}$ Caroli and Van Reenen (2001) were perhaps the first to identify this relationship.
} 
new workers formerly performed routine, cognitive tasks and were possibly the most productive of those workers, this will reduce wage inequality among routine, cognitive tasks, again consistent with the results above.

In this narrative there is not necessarily a formal role for organizational change, though it is important to note that the firm may report organizational change due to the fact that tasks have presumably been redistributed within the firm. Thus, our wage findings from above, combined with a role for organizational change, may still be consistent with the tasks-based mechanism. In contrast, Garicano and Rossi-Hansberg (2006) present a model in which organizational change plays a central role, and where reductions in the cost of ICT alter the relative importance of managers versus workers within the firm. In that model, the effects due to reductions in the cost of communication technologies (the Communications component of ICT) are quite different than those due to reductions in the cost of knowledge-acquisition technologies (the Information component of ICT). In short, they show that increased use of communications technologies widens inequality among managers while reducing inequality among workers, and has an ambiguous effect on between-group (manager vs worker) inequality. ${ }^{33}$ In contrast, increased use of information-acquisition technologies widens inequality within both groups of workers while also increasing between-group inequality.

Our empirical findings are therefore potentially consistent with the former effect, in which ICT investments are oriented toward reducing communication costs within the firm, thereby increasing wage dispersion among managers—-who perform non-routine, cognitive tasks—and decreasing wage dispersion among workers-who, if we set aside manual work since it is seemingly unaffected, perform routine, cognitive tasks. We also note that the results indicated a rise in between-group inequality (via a rise in the return to non-routine, cognitive tasks and a fall in the return to routine, cognitive tasks), which is consistent with both channels in the Garicano and Rossi-Hansberg (2006) model.

In an effort to identify the relevant mechanisms, we exploit the narrow focus on the managerial class in Garicano and Rossi-Hansberg (2006). Specifically, we apply the RD strategy to the set of workers in the ASHE whose occupation codes classify them as managers, and report the results in Figure 11 and Table 6.

\footnotetext{
${ }^{33}$ We should note that this is an overly simple characterization of their findings, in part because in the model a firm may have multiple layers of management.
} 
Figure 11: Wage Dispersion: Non-Routine Cognitive \& Managers

\section{A. Non-Routine Cognitive}

(1) Pre-Treatment

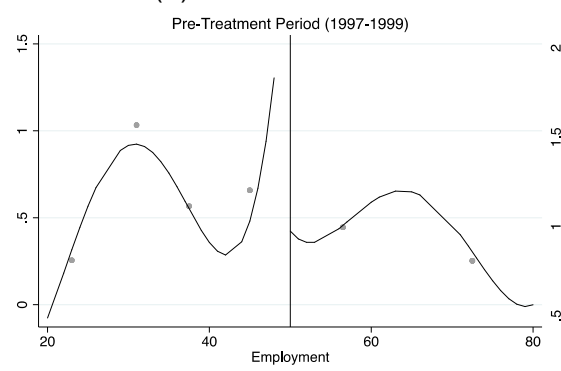

(1) Pre-Treatment

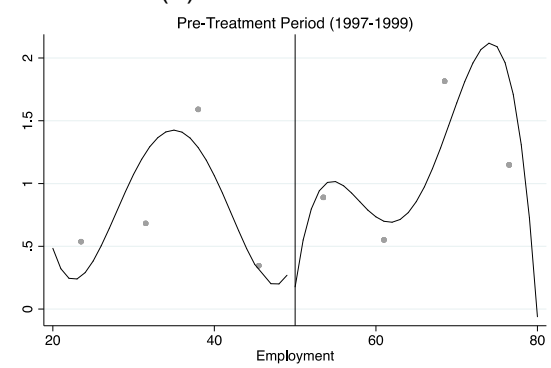

(2) Treatment

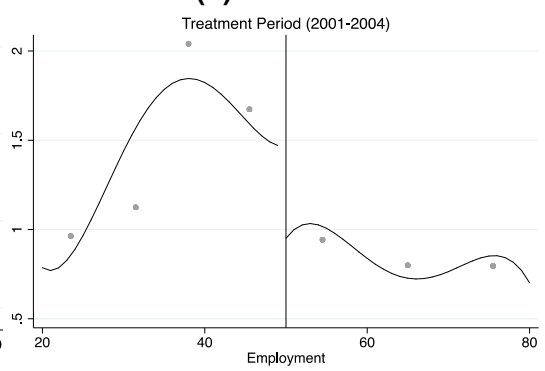

B. Managers

(2) Treatment

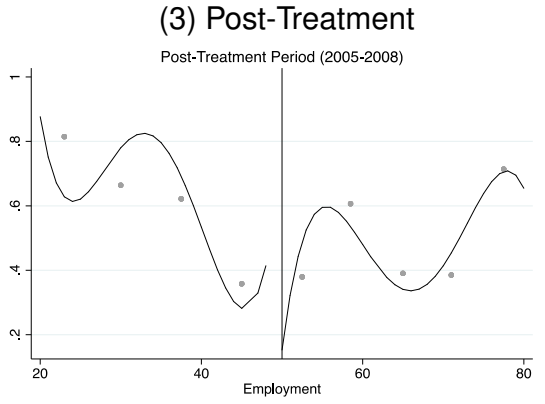

(3) Post-Treatment

Notes: The figures are constructed as in Figure 6 and report the log wage gap between the 90th and 10th percentile of the earnings distribution within non-routine cognitive workers and management occupations only. For all figures we choose the optimal bandwidth and bin size to the left and the right of the 50 employee cutoff based on the methods described in Calonico et al. (2015). The lines are fitted fourth order polynomials.

Since this group is a subset of the non-routine, cognitive group, we can ask whether the wage patterns we observe for the non-routine, cognitive group are driven primarily by managers, as predicted by Garicano and Rossi-Hansberg (2006), or by other workers who perhaps use the technology more directly, which would be more consistent with the tasks-based framework.

The results indicate no clear discontinuity in the managerial wage at the 50 employee threshold, suggesting that over the short time period examined here the forces described by the knowledge hierarchy model may not be relevant. This points to a more direct augmentation and substitution of labor within the firm, consistent with the tasks model. Finally, we note that this exercise is clearly suggestive, and not definitive, as there may be important forces operating that are outside either of these models. 
Table 6: Discontinuity in Worker Outcomes: Non-Routine Cognitive \& Managers

\begin{tabular}{|c|c|c|c|c|c|c|c|c|c|}
\hline & \multicolumn{3}{|c|}{ A. Pre-Treat.: 1997 - 1999} & \multicolumn{3}{|c|}{ B. Treatment: 2001 - 2004} & \multicolumn{3}{|c|}{ C. Post Treat.: 2005-2008 } \\
\hline & (A.1) & (A.2) & (A.3) & (B.1) & (B.2) & (B.3) & (C.1) & (C.2) & (C.3) \\
\hline & $\begin{array}{l}\text { Earn- } \\
\text { ings }\end{array}$ & Hours & $\begin{array}{l}\text { Wage } \\
\text { Disp. }\end{array}$ & $\begin{array}{l}\text { Earn- } \\
\text { ings }\end{array}$ & Hours & $\begin{array}{l}\text { Wage } \\
\text { Disp. }\end{array}$ & $\begin{array}{l}\text { Earn- } \\
\text { ings }\end{array}$ & Hours & $\begin{array}{l}\text { Wage } \\
\text { Disp. }\end{array}$ \\
\hline \multicolumn{10}{|c|}{ A. Non-Routine Cognitive } \\
\hline $\begin{array}{l}\text { RD Estimate } \\
\text { Std. Err. }\end{array}$ & $\begin{array}{l}-10.61 \\
(10.4)\end{array}$ & $\begin{array}{l}-0.46 \\
(0.35)\end{array}$ & $\begin{array}{l}-0.51 \\
(0.91)\end{array}$ & $\begin{array}{c}-42.3821^{\star \star \star} \\
(11.6154)\end{array}$ & $\begin{array}{c}-0.5285^{\star \star} \\
(0.2215)\end{array}$ & $\begin{array}{l}-0.341^{\star *} \\
(0.1611)\end{array}$ & $\begin{array}{c}-8.9 \\
(14.1)\end{array}$ & $\begin{array}{l}-0.14 \\
(0.29)\end{array}$ & $\begin{array}{l}-0.83 \\
(0.69)\end{array}$ \\
\hline Obs. & 110 & 109 & 95 & 114 & 117 & 114 & 115 & 106 & 117 \\
\hline Bandwidth & 59 & 58 & 47 & 63 & 66 & 63 & 64 & 55 & 66 \\
\hline \multicolumn{10}{|l|}{ B. Managers } \\
\hline $\begin{array}{l}\text { RD Estimate } \\
\text { Std. Err. }\end{array}$ & $\begin{array}{l}-10.64 \\
(10.81)\end{array}$ & $\begin{array}{l}-0.46 \\
(0.35)\end{array}$ & $\begin{array}{l}-0.45 \\
(0.48)\end{array}$ & $\begin{array}{r}-12.9022 \\
(9.9151)\end{array}$ & $\begin{array}{l}-0.1689 \\
(0.2982)\end{array}$ & $\begin{array}{l}-0.7445 \\
(0.6872)\end{array}$ & $\begin{array}{l}-2.94 \\
(4.92)\end{array}$ & $\begin{array}{l}-0.37 \\
(0.53)\end{array}$ & $\begin{array}{l}-0.42 \\
(0.34)\end{array}$ \\
\hline Obs. & 110 & 109 & 95 & 116 & 105 & 116 & 116 & 105 & 116 \\
\hline Bandwidth & 59 & 58 & 47 & 65 & 54 & 65 & 65 & 54 & 65 \\
\hline $\begin{array}{l}\text { Notes: The table } \\
\text { procedure descr } \\
\text { wage dispersion } \\
\text { each group. The } \\
\text { optimal firm-size } \\
\text { each coefficient }\end{array}$ & $\begin{array}{l}\text { reports lo } \\
\text { ed in Cal } \\
\text { neasured } \\
\text { optimal bo }\end{array}$ & $\begin{array}{l}\text { linear } \\
\text { ico et a } \\
\text { s the lo }\end{array}$ & wage $\mathrm{g}$ & $\begin{array}{l}\text { e regression } \\
\text { dependent va } \\
\text { etween the } 9 \\
\text { according to }\end{array}$ & $\begin{array}{l}\text { efficient } \tau \\
\text { bles are } \\
\text { and } 10 \text { th } \\
\text { lonico et }\end{array}$ & $\begin{array}{l}\text { in mode } \\
\text { weekly ec } \\
\text { rcentile } \\
(2014) \text { an }\end{array}$ & $\begin{array}{l}\text { ased or } \\
\mathrm{s},(2) \mathrm{w} \\
\text { earning } \\
\text { data ar } \\
\text { rted in }\end{array}$ & $\begin{array}{l}\text { e bias- } \\
\text { kly hou } \\
\text { distribu } \\
\text { aggrege }\end{array}$ & $\begin{array}{l}\text { rrection } \\
\text { and (3) } \\
\text { in within } \\
\text { d to the } \\
\text { s below }\end{array}$ \\
\hline
\end{tabular}

\section{Concluding Remarks}

Our short-run look at "what ICT does" refines the answer originally suggested by Autor et al. (2003). We find that the adoption of ICT leads to a rise in the demand for non-routine cognitive tasks, even within a horizon of only five years. At the same time, we find a modest tendency for ICT to replace routine cognitive work while manual work seems mostly unaffected.

We implement a research design that exploits exogenous variation in ICT investments generated by a temporary tax incentive. While economists have long sought to identify the conditions under which tax incentives are effective in stimulating investment demand (at least since Hall and Jorgenson's (1967) seminal work) a clear consensus has yet to emerge from this debate. ${ }^{34}$ Most of the extant empirical work, even when exploiting natural experiments, takes a structural approach which often requires the approximation of many model quantities that are not directly observed in the data (e.g., firm- and asset-specific depreciation and tax

\footnotetext{
${ }^{34}$ For a few important contributions see Lucas (1976), Jorgenson and Yun (1990), Auerbach and Hassett (1991, 1992), Cummins et al. (1994, 1996), Goolsbee (1998), Chirinko et al. (1999), Cohen and Cummins (2006), as well as House and Shapiro (2008).
} 
rates, the rental rate of capital, etc.) and that are conditional on the particular structural assumptions. In contrast, our research design relies on few identifying assumptions, which are likely to be satisfied.

Our short-run estimates provide insight into the nature of technological change in part because they implicitly highlight differences between the short- and long-run impact. Specifically, the modest impact on routine workers reflected in our estimates suggests an asymmetry in the timing of the organizational change that goes along with ICT adoption. New technologies may demand immediate engagement by workers with the skill and ability to execute non-routine cognitive tasks. As a result, organizational change-i.e., hiring and firing, extending worker hours, restructuring of workplace hierarchies, etc.—aligns itself with this requirement in the short run. There is seemingly less of a need in the short run to replace workers who previously performed the routine tasks that are now performed by ICT—-though, again, we do find evidence of some substitution. We also note that this asymmetry in timing is consistent with Jaimovich and Siu (2012), who find that about 92 percent of the routine jobs lost in the US since the 1980s were lost during a 12-month window following NBER dated recessions. This is despite the fact that aggregate investment is highly pro-cyclical, and therefore most investment—including ICT investment—happens during booms rather than immediate recoveries from a recession.

One of the standard predictions from neoclassical investment demand theory is that investment tax breaks—or, for that matter, any policy-induced reduction in the current price of investment goods—are only effective in altering the timing of investment. In this case, they will only stimulate current investment demand if they are expected to be sufficiently temporary and if the eligible assets are sufficiently long-lived. While the U.K. tax incentive studied here was indeed temporary, ICT capital is among the fastest depreciating forms of equipment, with annual depreciation rates of up to 30 percent. In light of this, the success of the ICT tax incentive explored here is somewhat puzzling. Some possible explanations include: (1) the tax incentive was quite generous (a 100 percent tax write-off); (2) computer purchases represent relatively small capital investments and therefore require less financial planning; (3) in 2000, the "computer revolution" was well under way and managers may have felt pressure to invest in ICT capital. We leave further exploration of this puzzle to future research.

Finally, we provide evidence on the relevance of recent theories of ICT adoption and wage inequality, finding that a tasks-based explanation best fits the patterns that we observe. 


\section{References}

Abramovsky L, Griffith R. 2006. Outsourcing and offshoring of business services: How important is ict? Journal of the European Economic Association 4: 594-601.

Acemoglu D. 1998. Why Do New Technologies Complement Skills? Directed Technical Change And Wage Inequality. The Quarterly Journal of Economics 113: 1055-1089.

URL http://ideas.repec.org/a/tpr/qjecon/v113y1998i4p1055-1089.html

Acemoglu D. 2002. Technical Change, Inequality, and the Labor Market. Journal of Economic Literature 40: 7-72.

URL http://ideas.repec.org/a/aea/jeclit/v40y2002ilp7-72.html

Acemoglu D. 2007. Equilibrium Bias of Technology. Econometrica 75: 1371-1409.

URL http://ideas.repec.org/a/ecm/emetrp/v75y2007i5p1371-1409.html

Acemoglu D, Aghion P, Lelarge C, Van Reenen J, Zilibotti F. 2006. Technology, information and the decentralization of the firm. Technical report, National Bureau of Economic Research.

Acemoglu D, Autor D. 2011. Skills, Tasks and Technologies: Implications for Employment and Earnings, volume 4 of Handbook of Labor Economics, chapter 12. Elsevier, 1043-1171.

URL http://ideas.repec.org/h/eee/labchp/5-12.html

Akcomak S, Kok S, Rojas-Romagosa H. 2013. The effects of technology and offshoring on changes in employment and task-content of occupations. CPB Discussion Paper 233, CPB Netherlands Bureau for Economic Policy Analysis.

URL http://ideas.repec.org/p/cpb/discus/233.html

Akerman A, Gaarder I, Mogstad M. 2013. The Skill Complementarity of Broadband Internet. IZA Discussion Papers 7762, Institute for the Study of Labor (IZA).

URL http://ideas.repec.org/p/iza/izadps/dp7762.html

Auerbach AJ, Hassett K. 1991. Recent U.S. investment behavior and the tax reform act of 1986: A disaggregate view. Carnegie-Rochester Conference Series on Public Policy 35: 185-215.

URL http://ideas.repec.org/a/eee/crcspp/v35y1991ip185-215.html

Auerbach AJ, Hassett K. 1992. Tax policy and business fixed investment in the United States. Journal of Public Economics 47: 141-170.

URL http://ideas.repec.org/a/eee/pubeco/v47y1992i2p141-170.html

Autor DH, Dorn D. 2013. The growth of low-skill service jobs and the polarization of the us labor market. American Economic Review 103: 1553-97.

URL http://ideas.repec.org/a/aea/aecrev/v103y2013i5p1553-97.html

Autor DH, Dorn D, Hanson GH. 2013a. The geography of trade and technology shocks in the united states. American Economic Review 103: $220-25$.

URL http://ideas.repec.org/a/aea/aecrev/v103y2013i3p220-25.html 
Autor DH, Dorn D, Hanson GH. 2013b. Untangling trade and technology: Evidence from local labor markets. NBER Working Papers 18938, National Bureau of Economic Research, Inc.

URL http://ideas.repec.org/p/nbr/nberwo/18938.html

Autor DH, Levy F, Murnane RJ. 2003. The skill content of recent technological change: An empirical exploration. The Quarterly Journal of Economics 118: 1279-1333.

URL http://ideas.repec.org/a/tpr/qjecon/v118y2003i4p1279-1333.html

Bartel A, Ichniowski C, Shaw K. 2007. How does information technology affect productivity? plant-level comparisons of product innovation, process improvement, and worker skills. The Quarterly Journal of Economics 122: 1721-1758.

URL http://ideas.repec.org/a/tpr/qjecon/v122y2007i4p1721-1758.html

Bartel AP, Ichniowski C, Shaw KL. 2005. How does information technology really affect productivity? plant-level comparisons of product innovation, process improvement and worker skills. Technical report, National Bureau of Economic Research.

Beaudry P, Doms M, Lewis E. 2010. Should the personal computer be considered a technological revolution? evidence from u.s. metropolitan areas. Journal of Political Economy 118: 988 - 1036.

URL http://ideas.repec.org/a/ucp/jpolec/doi10.1086-658371.html

Black SE, Lynch LM. 2001. How to compete: the impact of workplace practices and information technology on productivity. Review of Economics and statistics 83: 434-445.

Bøler EA, Moxnes A, Ulltveit-Moe KH. 2012. Technological change, trade in intermediates and the joint impact on productivity .

Bresnahan TF, Brynjolfsson E, Hitt LM. 1999. Information technology, workplace organization and the demand for skilled labor: firm-level evidence. Technical report, National bureau of economic research.

Brynjolfsson E, Hitt LM. 2003. Computing productivity: Firm-level evidence. The Review of Economics and Statistics 85: 793-808.

URL http://ideas.repec.org/a/tpr/restat/v85y2003i4p793-808.html

Calonico S, Cattaneo MD, Titiunik R. 2014. Robust nonparametric confidence intervals for regression-discontinuity designs. Econometrica 82: $2295-2326$

Calonico S, Cattaneo MD, Titiunik R. 2015. Optimal data-driven regression discontinuity plots. forthcoming in the Journal of the American Statistical Association .

Caroli E, Van Reenen J. 2001. Skill-biased organizational change? evidence from a panel of british and french establishments. Quarterly journal of economics : $1449-1492$.

Chirinko RS, Fazzari SM, Meyer AP. 1999. How responsive is business capital formation to its user cost?: An exploration with micro data. Journal of Public Economics 74: 53-80.

URL http://ideas.repec.org/a/eee/pubeco/v74y1999i1p53-80.html

Cohen D, Cummins J. 2006. A retrospective evaluation of the effects of temporary partial expensing. Finance and Economics Discussion Series 2006-19, Board of Governors of the Federal Reserve System (U.S.).

URL http://ideas.repec.org/p/fip/fedgfe/2006-19.html 
Colombo MG, Delmastro M. 2004. Delegation of authority in business organizations: an empirical test. The Journal of Industrial Economics 52: 53-80.

Cummins JG, Hassett KA, Hubbard RG. 1994. A Reconsideration of Investment Behavior Using Tax Reforms as Natural Experiments. Brookings Papers on Economic Activity 25: 1-74.

URL http://ideas.repec.org/a/bin/bpeajo/v25y1994i1994-2p1-74.html

Cummins JG, Hassett KA, Hubbard RG. 1996. Tax reforms and investment: A cross-country comparison. Journal of Public Economics 62: 237273.

URL http://ideas.repec.org/a/eee/pubeco/v62y1996i1-2p237-273.html

De Stefano T, Kneller R, Timmis J. 2014. The (fuzzy) digital divide: The effect of broadband internet use of uk firm performance .

DiNardo JE, Pischke JS. 1997. The Returns to Computer Use Revisited: Have Pencils Changed the Wage Structure Too? The Quarterly Journal of Economics 112: 291-303.

URL http://ideas.repec.org/a/tpr/qjecon/v112y1997i1p291-303.html

Doms M, Dunne T, Troske KR. 1997. Workers, wages, and technology. The Quarterly Journal of Economics 112: 253-90.

URL http://ideas.repec.org/a/tpr/qjecon/v112y1997i1p253-90.html

Doms M, Lewis E. 2006. Labor supply and personal computer adoption. Working Papers 06-10, Federal Reserve Bank of Philadelphia.

URL http://ideas.repec.org/p/fip/fedpwp/06-10.html

Draca M, Sadun R, van Reenen J. 2006. Productivity and ICT: A Review of the Evidence. CEP Discussion Papers dp0749, Centre for Economic Performance, LSE.

URL http: / /ideas.repec.org/p/cep/cepdps/dp0749.html

Gaggl P, Wright GC. 2014. A short run view of what computers do: Evidence from a uk tax incentive. Technical report, UNC Charlotte.

URL http: / / belkcollegeofbusiness.uncc.edu/pgaggl/research/docs/UK_ICT_6-12-2014_WP.pdf

Garicano L, Rossi-Hansberg E. 2006. Organization and Inequality in a Knowledge Economy. The Quarterly Journal of Economics 121: $1383-1435$.

URL http://ideas.repec.org/a/tpr/qjecon/v121y2006i4p1383-1435.html

Garicano L, Rossi-Hansberg E. 2014. Knowledge-based hierarchies: Using organizations to understand the economy. Technical report, National Bureau of Economic Research.

Goldin C, Katz L. 2008. THE RACE BETWEEN EDUCATION AND TECHNOLOGY. Harvard University Press. ISBN 9780674028678.

URL http: / /books.google.com/books?id=mcYsvvNEUYwC

Goolsbee A. 1998. Investment Tax Incentives, Prices, And The Supply Of Capital Goods. The Quarterly Journal of Economics 113: $121-148$.

URL http://ideas.repec.org/a/tpr/qjecon/v113y1998i1p121-148.html

Hall RE, Jorgenson DW. 1967. Tax policy and investment behavior. The American Economic Review 57: pp. 391-414. ISSN 00028282.

URL http: //www.jstor.org/stable/1812110

House CL, Shapiro MD. 2008. Temporary Investment Tax Incentives: Theory with Evidence from Bonus Depreciation. American Economic Review 98: $737-68$.

URL http://ideas.repec.org/a/aea/aecrev/v98y2008i3p737-68.html 
Imbens GW, Lemieux T. 2008. Regression discontinuity designs: A guide to practice. Journal of econometrics 142: 615-635.

Jaimovich N, Siu HE. 2012. The trend is the cycle: Job polarization and jobless recoveries. Working Paper 18334, National Bureau of Economic Research.

URL http://www.nber.org/papers/w18334

Jorgenson DW, Yun KY. 1990. Tax reform and u.s. economic growth. Journal of Political Economy 98: pp. S151-S193. ISSN 00223808. URL http: //www.jstor.org/stable/2937635

Krueger AB. 1993. How Computers Have Changed the Wage Structure: Evidence from Microdata, 1984-1989. The Quarterly Journal of Economics 108: $33-60$.

URL http://ideas.repec.org/a/tpr/qjecon/v108y1993ilp33-60.html

Lee DS, Card D. 2008. Regression discontinuity inference with specification error. Journal of Econometrics 142: 655-674.

URL http://ideas.repec.org/a/eee/econom/v142y2008i2p655-674.html

Lee DS, Lemieux T. 2009. Regression discontinuity designs in economics. Technical report, National Bureau of Economic Research.

Lucas RJ. 1976. Econometric policy evaluation: A critique. Carnegie-Rochester Conference Series on Public Policy 1: 19-46.

URL http://ideas.repec.org/a/eee/crcspp/v1y1976ip19-46.html

Michaels G, Natraj A, van Reenen J. 2014. Has ICT Polarized Skill Demand? Evidence from Eleven Countries over Twenty-Five Years. The Review of Economics and Statistics 96: 60-77.

URL http://ideas.repec.org/a/tpr/restat/v96y2014i1p60-77.html 